Full length Article

\title{
Mélange versus forearc contributions to sedimentation and uplift, during rapid denudation of a young Banda forearc-continent collisional belt
}

\author{
Brendan Duffy $^{\mathrm{a}, \mathrm{b}, *}$, Julie Kalansky ${ }^{\mathrm{c}, \mathrm{d}}$, Kari Bassett ${ }^{\mathrm{b}}$, Ron Harris ${ }^{\mathrm{e}}$, Mark Quigley ${ }^{\mathrm{a}, \mathrm{b}}$, \\ Douwe J.J. van Hinsbergen ${ }^{f}$, Lorna J. Strachan ${ }^{g}$, Yair Rosenthal ${ }^{\mathrm{d}}$ \\ a School of Earth Sciences, University of Melbourne, Victoria, Australia \\ ${ }^{\mathrm{b}}$ Department of Geological Sciences, University of Canterbury, New Zealand \\ ${ }^{\mathrm{c}}$ Scripps Institution of Oceanography, UC San Diego, United States \\ ${ }^{\mathrm{d}}$ Rutgers Institute of Marine and Coastal Sciences, New Brunswick, NJ, United States \\ e Department of Geological Sciences, Brigham Young University, Provo, UT, United States \\ ${ }^{\mathrm{f}}$ Department of Earth Sciences, Utrecht University, Utrecht, Netherlands \\ ${ }^{\mathrm{g}}$ School of Environment, University of Auckland, New Zealand
}

\section{A R T I C L E I N F O}

\section{Article history:}

Received 16 August 2016

Received in revised form 27 January 2017

Accepted 5 February 2017

Available online 10 February 2017

\section{Keywords:}

Timor

Banda

Arc-continent collision

Mélange

Reworking

$\mathrm{Sm} / \mathrm{Nd}$

Surface uplift

Sedimentary geochemistry

\begin{abstract}
A B S T R A C T
New sedimentary geochemistry and petrographic analyses provide the most extensive sedimentary documentation yet of the rapid denudation of the young Timor orogen. The data from three basins including two widely-separated, well-dated sections of the Synorogenic Megasequence of Timor-Leste, and a redated DSDP 262, constrain the source and timing of detrital sediment flux during forearc-continent collision along the Timor sector of the Banda Arc. The exhumed synorogenic piggy-back basins formed above a mélange unit that developed at the expense of a weak stratigraphic horizon in the Mesozoic stratigraphy, and was exhumed to the sea floor in latest Messinian time. Following an interval of deep marine chalky marl sedimentation, an increasingly muddy sediment flux indicates that the island of Timor became emergent and shed sediment by $4.5 \mathrm{Ma}$. Comparison of exhumed sections with similar patterns in the DSDP262 chemistry suggests that the sediment source was probably located some $50-60 \mathrm{~km}$ distant from the basin, which is consistent with the Aileu region of Timor-Leste that shows an appropriate exhumation history. All sedimentation between 4.5 and 3.2 Ma was probably derived from a low-relief, rapidly eroding, and mudstone-dominated landscape with geochemical affinities to the Triassicmudstone-derived synorogenic mélange. The mélange unit overlies and surrounds the Banda Terrane, and was presumably structurally emplaced by propagation of a decollement through the Triassic rocks during the collision. After 3.2 Ma, sedimentation was dominated by hard rock lithologies of the Banda Terrane, consisting of forearc cover and basement, the latter including elements of metamafic rocks and metapelites. This phase of sedimentation was accompanied by rapid uplift, which may have been partly driven by a transient imbalance between rock uplift and denudation as resistant lithologies emerged from below mélange-like mudstone. Previous work has suggested that the timing of collision in Timor-Leste and West Timor was substantially different. Our reevaluation of DSDP 262 facies migration history in the context of the re-dating presented here, favours a relatively synchronous onset of uplift in both halves of the island, but with different partitioning of strain between the foreland and hinterland in each half of the island.
\end{abstract}

(c) 2017 Elsevier Ltd. All rights reserved.

\section{Introduction}

A diversity of processes including magmatism, deformation, mélange generation, uplift, erosion and associated unroofing

\footnotetext{
* Corresponding author at: School of Earth Sciences, University of Melbourne, Victoria, Australia.
}

E-mail address: brendan.duffy@unimelb.edu.au (B. Duffy). accompany forearc or arc continent collision events. The relative importance of these processes changes during these collisional events and associated sedimentation is modulated by parameters such as the collisional kinematics, stratification and inherited structure, composition and rheology of both the upper and lower plates (e.g., Afonso and Zlotnik, 2011; Brown et al., 2011; Duffy et al., 2013; Harris, 2011; Harris et al., 1998), as well as by climatic factors such as weathering and orographic weather patterns. Dis- 
membered remnants of syn-collisional sedimentary basins are rare, but where present they can elucidate the short-lived and dynamic interplay of these processes as oceanic subduction complexes give way to arc-continent collision (Bayona et al., 2011; Dewey and Mange, 2000; Guo et al., 2012; Ryan, 2008; Tate et al., 2014; Zhu et al., 2005). Carefully documented examples of the evolution of young, well-exposed and dated basins, with clear geodynamic context (e.g., Dorsey, 1988; Nagel et al., 2014) provide a critical resource against which to evaluate the ability of syncollisional sediments to accurately reflect and record the signals that are routinely extracted from them. In particular, analysis of a young orogen might be expected to provide a unique archive of the rates at which processes of early orogenesis can occur, including the timing and drivers of various tectonic phases (De Smet et al., 1990), the lithological characteristics of the source areas (Floyd et al., 1990), the history of erosional unroofing (DeCelles et al., 1998) and the relatively undocumented importance of reworking of the shale-dominated mélanges that are a ubiquitous and persistent component of collisional orogenesis (Barber, 2013; Festa et al., 2010).

The island of Timor is a contractional orogen located within the zone of collision between the Wetar sector of the Banda Forearc and the Australian continental margin, and in a region that has been the focus of recent reevaluation of its collisional history. Since the 1990s, several studies have attributed Timor's development to underthrusting of a promontory on Australia's NW shelf but the subsequent style of deformation remains debated (Duffy et al., 2013; Harris, 1991; Keep and Haig, 2010; Snyder et al., 1996; Tate et al., 2015). DSDP 262 was drilled in the 1970s to core the Timor Trough sediments, about $800 \mathrm{~m}$ south of the trough axis. The analysis of this core provided some evidence for the tectonic history of the trough, but dating of the core was problematic and age models variable (Heirtzler et al., 1974; Johnston and Bowin, 1981; Veevers et al., 1978). Multiple lines of evidence including palynology, foraminiferal micropaleontology and biomagnetostratigraphy suggest that Timor began uplifting from near-CCD depths prior to 4.5 Ma (Aben et al., 2014; Haig and McCartain, 2007; Nguyen et al., 2013; Tate et al., 2014), during a collisional history that may have begun prior to 7 Ma (Keep and Haig, 2010; Tate et al., 2014). Now, only remnants of the uplifted forearc crust remain (Standley and Harris, 2009), and Australian-affinity rocks including a widespread tectonic mélange and broken formation crop out across much of the island (Barber et al., 1986; Harris et al., 1998). Synorogenic piggy-back basins accumulated deepmarine marls and turbiditic sandstones on the lower northern slope of the Timor Trough; exhumed examples containing up to $1 \mathrm{~km}$ of sediment are found distributed around Timor. Two of these basins, the Marobo and Viqueque basins (Fig. 1b), contain welldated sections with strong paleo-topographic and paleobathymetric constraints (Aben et al., 2014; Nguyen et al., 2013; Quigley et al., 2012; Tate et al., 2014). However, their provenance has not been systematically evaluated.

The good age control on the Timor-Leste sections, and our new age data for the DSDP 262 site in the Timor Trough, together with the coarse grained nature of Timor-Leste's synorogenic basins, provide a useful opportunity to evaluate their provenance, relate it to the published spatiotemporal patterns of exhumation, uplift and structural development (Tate et al., 2014, 2015), and examine the importance of mélange reworking in nascent collision zones. We address this opportunity by investigating the petrographic and geochemical stratigraphy of the exhumed carbonate, marl and siliciclastic coarsening-up succession, using the stratigraphic control of two of the basins in central and east Timor Island (Aben et al., 2014; Haig and McCartain, 2007; Tate et al., 2014) to identify evolutionary trends. We compare our data with the DSDP 262 drill site in the Timor Trough (Fig. 1), for which we present a refined age model, and studies from West Timor and islands to the west (Roosmawati and Harris, 2009). In this way, we provide a new spatio-temporal perspective on the geodynamic evolution of the Timor forearc-continent collision zone and important new insights into the importance of mélange reworking for mudstone provenance and episodic uplift.

\section{Geology and pre-collisional stratigraphy of Timor}

The Australian plate in the Timor Sea region presently travels NNE at $\sim 70 \mathrm{~mm} \mathrm{yr}^{-1}$ relative to the Sunda Shelf (Bock et al., 2003; Genrich et al., 1996; Koulali et al., 2016; Kreemer et al., 2000; Nugroho et al., 2009) (Fig. 1a). Subduction of old oceanic lithosphere north of what is known as the Banda Embayment of the Australian continental margin began around $12 \mathrm{Ma}$ or shortly before and propagated eastward, resulting in development of the Banda Arc as an eastwards extension of the Sunda Arc (Abbott and Chamalaun, 1981; Hinschberger et al., 2001; Pownall, 2015; Pownall et al., 2014, 2013; Spakman and Hall, 2010). Southeastdirected rollback of the subducting plate into the Banda Embayment caused supra-subduction zone spreading in the upper plate to form the Banda Sea (Spakman and Hall, 2010). The collisional history of Timor since that time is strongly debated (AudleyCharles, 2011; Charlton, 2002b; Duffy et al., 2013; Harris, 2011; Keep and Haig, 2010; Tate et al., 2014, 2015), but seems to have begun as early as $\sim 8 \mathrm{Ma}$, probably as a result of underthrusting of a promontory on the NW Australian margin (Berry and McDougall, 1986; Duffy et al., 2013; Keep and Haig, 2010; Snyder et al., 1996; Tate et al., 2014). Only remnants of the exhumed forearc basement are preserved, while the previous work on synorogenic provenance suggests that several kilometers of forearc has been eroded away and incorporated in the sedimentary fill of synorogenic basins (Audley-Charles, 1967, 1968; Kenyon, 1974). Some of these sediments have been uplifted and are widely exposed in the synorogenic basins of Timor and islands to the west (Audley-Charles, 1968; Fortuin et al., 1997; Kenyon, 1974; Roosmawati and Harris, 2009) (Fig. 1b), where they preserve a sedimentary archive of the collisional evolution of the western Banda Orogen. The synorogenic sediments of these basins are locally observed lying unconformably on Australian affinity mélange and broken formation (Haig and McCartain, 2007), but in most cases have a very irregular contact with underlying and locally diapiric mélange (Duffy et al., 2013).

The island of Timor presently comprises five tectonostratigraphic units (Haig et al., 2007; Harris, 2011) (Fig. 2): (1) the uppermost Carboniferous to Jurassic Gondwana Megasequence of rift-basin rocks; (2) the Jurassic to Neogene Australian Passive Margin Megasequence; (3) a Miocene to recent synorogenic mélange generally considered to be derived from the Australianaffinity rocks; (4) Banda Terrane forearc rocks that we regard as an overthrust sheet but will show in this paper must have had a significant thickness of mélange-like Australian shales emplaced above it early in the collision, and (5) uppermost Miocene to Recent piggy-back basin deposits of the Synorogenic Megasequence (Fig. 2). The pre-orogenic lithologies are summarized in SupplementaryTable S1.

\subsection{Gondwana megasequence}

The Gondwana Megasequence (Haig et al., 2007) occupies most of the northern three quarters of modern-day Timor (Fig. 1). It was deposited in an interior rift basin on the northern margin of Gondwana during the Permian and Triassic (Charlton et al., 2002; Metcalfe, 1996) and consists of the proximal facies of the Kekneno Sequence (Charlton et al., 2002, 2009; Simons, 1940), and the over- 


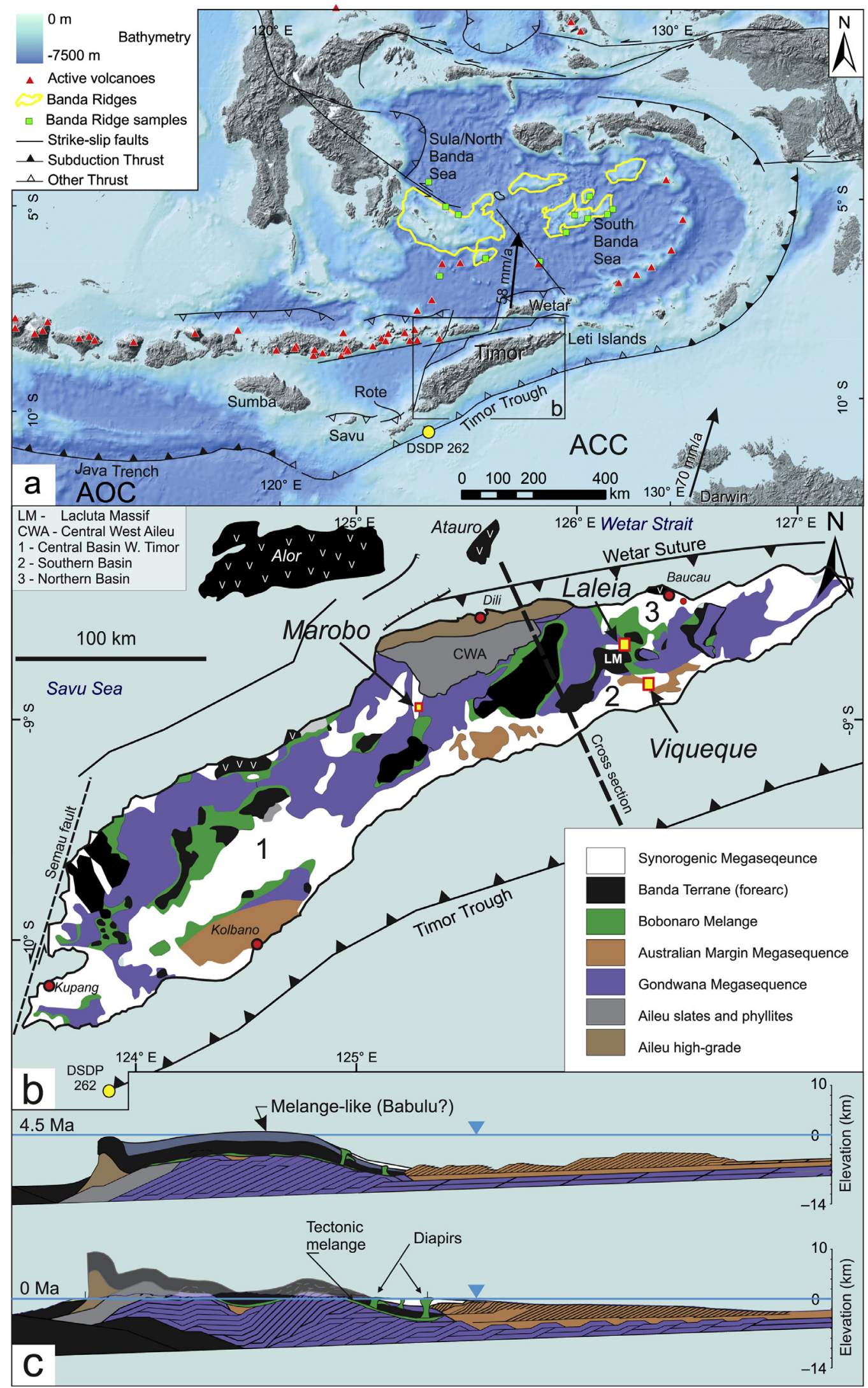

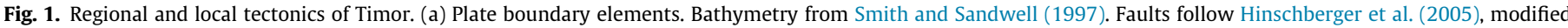

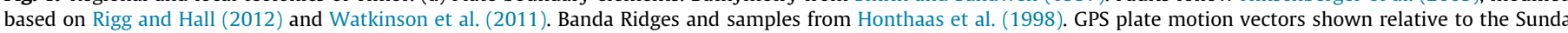

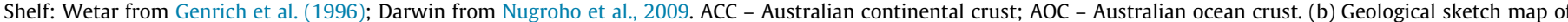

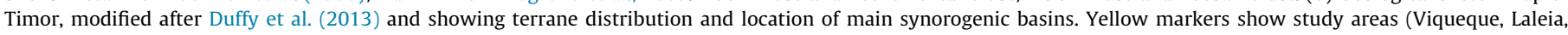

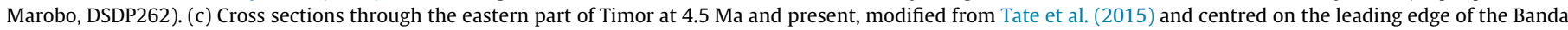
Terrane. (For interpretation of the references to color in this figure legend, the reader is referred to the web version of this article.) 


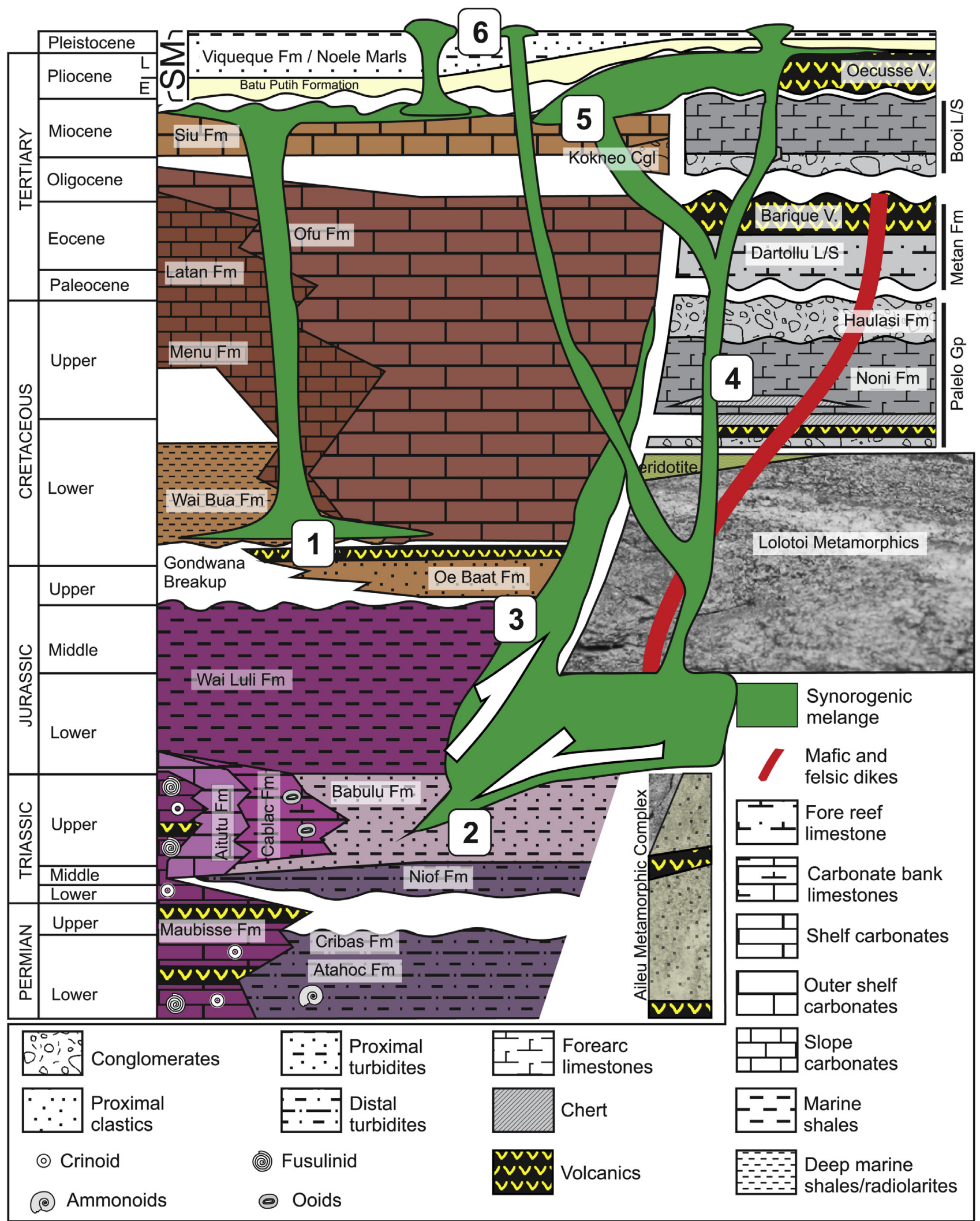

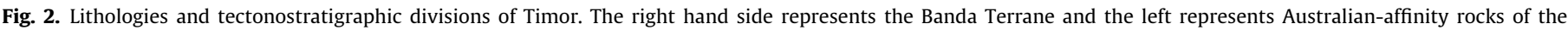

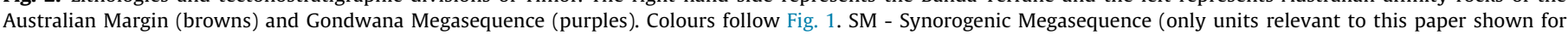

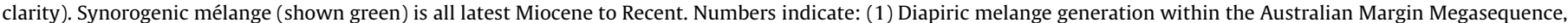

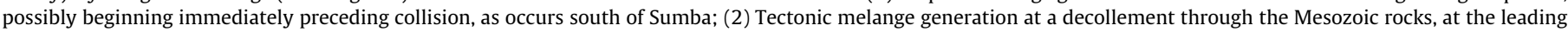

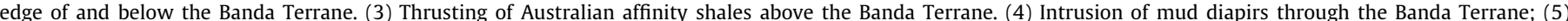

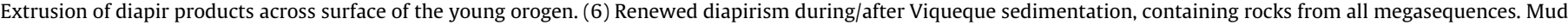
volcanism is ongoing. (For interpretation of the references to color in this figure legend, the reader is referred to the web version of this article.) 
thrust, distal facies found in the Alieu and Maubisse Nappe (Audley-Charles, 1968). Recent geochronological and geochemical constraints strongly support a Gondwana rather than Banda association for the Aileu Metamorphics (Boger et al., 2016). The distal facies includes distinctive fauna and lithologies including crinoidal and fusulinid limestones, many of which are silicified (Barkham, 1993; Charlton et al., 2002) in a manner that is characteristic of Paleozoic fossils (Schubert et al., 1997). Mafic and minor felsic rift basin, within-plate and ocean-ridge volcanics are common (Charlton et al., 2009; Haig et al., 2008). Petrographically distinctive lithologies below the Aileu/Maubisse nappe include Triassic/Jurassic oolitic carbonate bank limestones (Charlton et al., 2009; Haig et al., 2008).

\subsection{Australian margin megasequence}

The Australian Margin Megasequence (Haig et al., 2007), also known as the Kolbano Megasequence (Audley-Charles et al., 1979; Charlton, 1989), was deposited on a passive margin at the outer edge of a continental terrace off the NW shelf of Australia, which formed by subsidence after continental break up at around 155 Ma (Charlton, 1989). The Australian Margin Megasequence is very fine grained. It consists of red shales, radiolarites and red, pink and white bedded cherts that pass upwards or laterally into white, extensively slumped planktic foraminiferal calcilutites that make up most of the sequence (Audley-Charles, 1968; Charlton, 1989; Sawyer et al., 1993).. An imbricate stack of Cretaceous to Pliocene Australian Continental Margin Sequence is found in SW Timor where the sequence is repeated 18 times in onshore exposures (Harris, 2011) and many more times in the offshore (Sani et al., 1995). In West Timor, Oe Baat Formation conglomerates and sandstones lie at the base of the Australian Margin Megasequence (Charlton and Wall, 1994). Similar units, such as are associated with increased diapirism in the Barbados accretionary prism (Brown and Westbrook, 1988), have not been reported in East Timor.

\subsection{Banda Terrane}

The Banda Terrane is widely distributed as klippen and horst blocks throughout Timor (Standley and Harris, 2009). It is a diverse unit of crystalline oceanic basement, amphibolites, and volcanic and sedimentary cover rocks, derived from the forearc region of the Banda Arc (Harris, 2006). The Banda basement is composed of medium-pressure and temperature regionally metamorphosed and partly retrogressed sedimentary and volcanic rocks (AudleyCharles, 1968; de Roever, 1940; Harris, 2006; Park et al., 2014; Standley and Harris, 2009). The cover consists of a mix of Cretaceous to Oligocene volcaniclastics, turbidites and carbonates and includes radiolarian cherts, which are reworked into younger deposits (Earle, 1983). Distinctive lithologies include oolitic grainstones from the Palelo Group (Standley and Harris, 2009) and calcareous algal Alveolinea limestones from the Eocene biocalcarenites (Audley-Charles, 1968, p. 22). Tuffaceous units are dominated by basaltic, andesitic and dacitic rocks, the latter commonly altered to chlorite and carbonate. Dark greenish black, veined serpentinites are common and occasionally contain large clear crystals of olivine (Audley-Charles, 1968). Diorite dikes commonly intrude the full thickness of the Banda Terrane (Earle, 1980; Rosidi et al., 1981; Standley and Harris, 2009; van West, 1941).

We consider that the data to hand, including the present paper and previously published mapping and age data from the metamorphic rocks and cover units (Harris, 2006), are inconsistent with a model in which the Lolotoi Metamorphics are interpreted as Australian basement (e.g., Charlton, 2002a).

\subsection{Synorogenic Mélange}

The Synorogenic Mélange (Haig et al., 2007) [also known as the Sonnebait Series (Brouwer, 1942; de Roever, 1942; Simons, 1940) or the Bobonaro Scaly Clay (Audley-Charles, 1968; Barber, 2013)] is a clay matrix-rich tectonic mélange that occurs widely around the base of the Banda Terrane nappe (Harris et al., 1998, 2009) and along strike-slip faults in West Timor (Barber et al., 1986) and Timor-Leste (Duffy et al., 2013). It is commonly diapiric (Barber, 2013; Duffy, 2013) and locally intrudes into the synorogenic rocks. The mélange is usually interpreted to be sourced from sequences that remobilized as a result of overpressuring during thrusting (Barber et al., 1986; Harris, 2011; Harris et al., 1998). However, it is a complex unit that commonly contains lithologies derived from both Australian and Banda affinity units, and large blocks of mantle peridotite. Different structural associations have different block provenance (Haig and Bandini, 2013; Harris et al., 1998); in Fig. 2, we show that at least two argillaceous Australian-affinity units probably contribute to the mélange; either or both units may be present dependent on setting, and overlying competent lithologies may be plucked and incorporated into the mélange. Structures at the deformation front south of Sumba indicate that a mélange of overpressured mudstone is diapirically remobilized into the cores of ramp anticlines, creating diapiric ridges in front of the frontal thrust (Breen et al., 1986). Younger deformation, ongoing/renewed diapirism and landsliding may further disrupt older mélanges (Barber, 2013).

The Synorogenic Mélange of Timor-Leste contains 10\% quartz (Audley-Charles, 1965). In West Timor, the clays are likely sourced from the Lower Jurassic to Cretaceous Australian-affinity rocks that bound the breakup unconformity, and are smectite rich. Illite, kaolinite and chlorite rich clays occur within the Permian to Upper Triassic Gondwanan Megasequence rocks (Harris et al., 1998).

\section{Synorogenic geology of Timor}

\subsection{Stratigraphy}

The rapid Pliocene uplift and erosion of proto-Timor (Nguyen et al., 2013) was accompanied by deposition of the Synorogenic Megasequence of Timor-Leste, which is now well exposed in uplifted basins mostly on the south side of Timor (AudleyCharles, 1968; Haig et al., 2007) (Fig. 1). In general terms, the Synorogenic Megasequence comprises a gently deformed, coarsening upward succession that began depositing during the latest Miocene. The synorogenic nomenclature of Timor preferred in this study, along with other modern and historical usages, and possible confusions are summarized in Table S2.

The base of the Synorogenic Megasequence consists of basal chalk and marl, known as the Batu Putih Formation (Hopper, 1942; Kenyon, 1974) that ranges from the uppermost Miocene to Lower Pliocene (Aben et al., 2014; Haig and McCartain, 2007; Tate et al., 2014). The name Batu Putih Formation is widely used for the basal pelagic carbonate rocks throughout Timor, Savu, Rote and Sumba Islands of the western Banda orogen (Harris et al., 2009; Roosmawati and Harris, 2009). It was initially considered part of the Viqueque Formation (Kenyon, 1974), which is now known as the Synorogenic Megasequence (Haig et al., 2007). For the sake of consistency we restrict the name "Viqueque Formation" for marine clastic detrital sediments that overlie the Batu Putih Formation. The Viqueque Formation of Timor-Leste is dominated by middle to Upper Pliocene deep marine sandstones and conglomerates.

The Batu Putih Formation and Viqueque Formation are the focus of this study. The Synorogenic Megasequence also includes 
Viqueque Formation age-equivalent coral debris flows (the Lari Guti Formation) and Pleistocene fan delta conglomerates and siltstones (the Dilor Conglomerate). The Synorogenic Megasequence is capped by the Baucau Limestone, a Quaternary reef limestone that is commonly uplifted to elevations as high as $1000 \mathrm{~m}$ on both sides of the Wetar Strait north of Timor (Chappell and Veeh, 1978; Cox, 2009; Ely et al., 2011; Merritts et al., 1998; Rosidi et al., 1981; Vita-Finzi and Hidayat, 1991).

\subsection{Basin setting and deformation}

The Batu Putih Formation is the oldest of the synorogenic units of Timor and the thickest accumulations are found in normal-fault-bounded piggy back basins on the flanks of the young orogen. The basins are interpreted to have formed during early collisional collapse of the orogenic taper as the basal decollement propagated into the weak mudstones of the distal Australian continental margin (e.g., Harris et al., 1998); kinematic analyses indicate that this was followed by deep-seated arc-parallel extension, possibly driven by roll-back of the Banda slab around the colliding promontory (Duffy et al., 2013). Contractional processes are still considered to be active (Tate et al., 2014). The synorogenic rocks throughout the western Banda Orogen and at the type locality of the Viqueque Formation (south coast of Timor Leste) are pierced in several places by diapirs of synorogenic mélange that contain rocks from all of the major tectonostratigraphic units including the Banda Terrane (Duffy, 2013). In some places these diapirs feed active mud volcanoes extruding mélange.

\section{Previous work and relevant geochemical datasets}

The provenance of the synorogenic basins of Timor has only been qualitatively evaluated and the sediments are generally assumed to be derived largely from the Banda Terrane forearc basement (Audley-Charles, 1967, 1968; Kenyon, 1974). A wealth of potentially useful geochemical datasets are emerging that allow this hypothesis to be refined. The geochemistry of igneous and metamorphic rocks of the Banda Terrane are reported by Harris (1992), Harris (Harris, 2006), Standley and Harris (2009) and Park et al. (2014). For the Banda volcanic islands geochemical studies are reported by Ely et al. (2011 - Atauro), Elburg et al. (2005 Wetar, including Nd isotopes) and Herrington et al. (2011 - also Wetar). Ultramafic rock geochemistry for Timor are characterized by Harris (1992), Harris and Long (2000), and Falloon et al. (2006). Gondwanan rift-affinity volcanic rocks are reported by Berry and Jenner (1982). Major and trace element geochemistry and XRD mineralogy were reported for sediments from the DSDP 262 site in the Timor Trough (Cook, 1974a; Cooks et al., 1974), a site for which we present new age data. Vroon et al. (1995, 1993 ) reported the trace element and Nd isotope geochemistry of modern sea floor sediments along a transect across the orogenic wedge east of Timor Leste. Their data included the NW shelf of Australia and further data from five DSDP 262 core samples. Honthaas et al. (1998) and Vroon et al. (1996) reported similar data for rocks dredged from the Banda Ridges, which are lithologically similar and tectonically related to the Banda Terrane (Harris, 2006). Boger et al. (2016) reported whole rock geochemistry and $\mathrm{Nd}$ isotope data for the Babulu Formation (usually considered the dominant source of the mélange) and weakly metamorphosed shales of the Gondwanan Aileu Metamorphic Complex. Taylor and McLennan (1985) published detailed geochemical analyses for Australian shales and Allègre and Rousseau (1984) published their $\mathrm{Nd}$ isotope characteristics.

\section{Methods}

This study compares descriptions and geochemical data for conglomerate clasts, sandstones and mudstones derived from the synorogenic basins of Timor-Leste, with lithologies and relevant geochemical datasets from the various terranes.

\subsection{Measured sections}

We measured and sampled stratigraphic sections in the Viqueque and Marobo basins of Timor-Leste and related these sections to published biostratigraphy (Haig and McCartain, 2007; Tate et al., 2014) and magnetostratigraphy (Aben et al., 2014). These sections provide a stratigraphic context for our analyses.

\subsection{Conglomerate and sandstone petrography}

Thin sections of samples from the Marobo, Laleia and Viqueque Basins were analyzed by point counting. The tectonic setting of the sediments is not in question so, rather than using traditional point counting techniques, preference was given to conglomerate samples and point counting took the place of clast counts, for which there was no time in the field. The poorly lithified, fine to medium pebble conglomerate samples were disaggregated by hand and sieved to retain the $1 \mathrm{~mm}$ to $4 \mathrm{~mm}$ fraction, so as to preferentially observe identifiable lithics. Several sandstones from the Viqueque Formation type section were also thin sectioned and counted for comparison. The results are presented in Supplementary Table S3 and summarized at the end of the table.

\subsection{Geochemistry}

Carbonate, mudstone and conglomerate-clast samples were selected from the Viqueque Type section and the Marobo section and analyzed to determine their major and trace element geochemistry, and weight loss on ignition. Samples were analyzed at the commercial ALS Minerals laboratory at Winnemucca, Nevada. Major elements were determined using Inductively Coupled Plasma - Atomic Emission Spectroscopy (ICP-AES), and trace element geochemistry was determined using ICP Mass Spectrometry (ICP-MS) following standard procedures (ALS, 2006, 2009).

Loss on ignition (LOI) refers to the weight loss of a sample following combustion in a furnace and is dependent on temperature and duration of combustion. Different temperatures of combustion affect different changes in the composition of the sediment. Weight loss at $105^{\circ} \mathrm{C}$ reflects sediment water loss and is not considered further here. Loss on ignition at $550{ }^{\circ} \mathrm{C}$ $\left(\mathrm{LOI}_{550}\right)$ is generally considered to be proportional to the total organic carbon content of the sediment (Dean, 1974) but may also be contributed to by the loss of structural water in clay, which may account for $<20 \%$ weight loss in clay rich samples (Mook and Hoskin, 1982; Santisteban et al., 2004). XRD results indicate that the rocks analyzed here had minimal clay content, so $\mathrm{LOI}_{550}$ is taken to reflect organic carbon content. At higher temperatures, the dominant factor that creates weight loss in carbonates between 550 and $1000^{\circ} \mathrm{C}$ (reported as $\mathrm{LOI}_{1000}$ ) is the loss of carbonate $\mathrm{CO}_{2}$, such that carbonate content can be estimated from $\mathrm{LOI}_{1000}$ if $\mathrm{LOI}_{550}$ has previously been determined. When this relationship is applied, carbonate estimation error is proportional to clay content and inversely proportional to carbonate content (Santisteban et al., 2004). As noted above, the rocks analyzed here had minimal clay content. 
The samples for these analyses were selected to obtain a reasonable spread of ages. The base of the section, where age models show low sedimentation rates, was therefore sampled at closer intervals.

$\mathrm{Nd}$ isotope analyses were carried out to determine the bulk provenance age of the sediments. Analyses were performed at the University of Alberta following procedures outlined in Creaser et al. (1997) and Unterschutz et al. (2002).

\section{a}

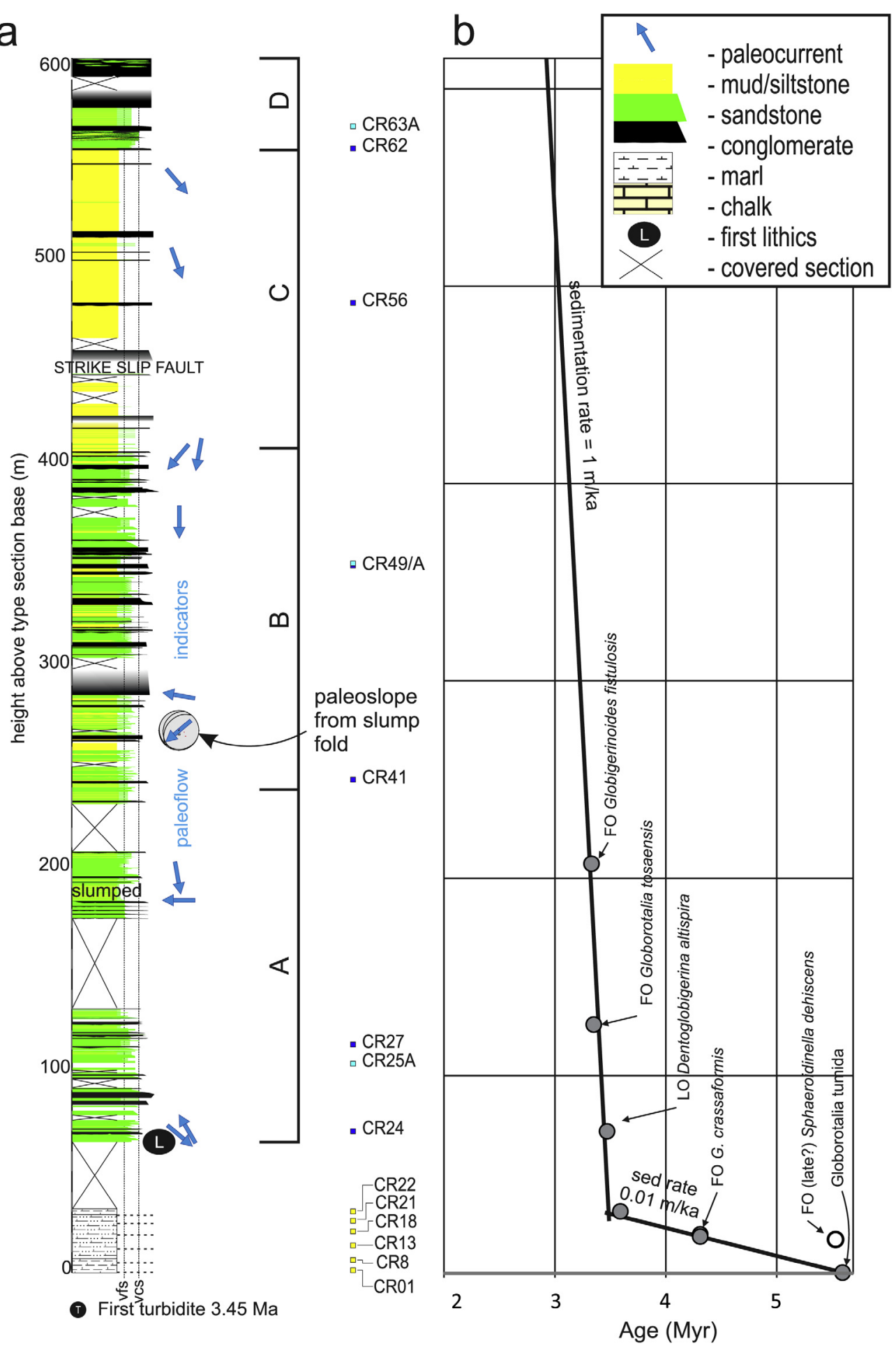

\section{Sections and age models}

\subsection{Marobo basin}

Tate et al. (2014) and Aben et al. (2014) dated a section of the Marobo Basin (Duffy et al., 2013) (Fig. 1b). The section location in the Cailaco River is shown in Supplementary Fig. S1 and the measured section in Fig. 3. The base of the section consists of less than $2 \mathrm{~m}$ of massive, creamy, moderately indurated foraminiferal

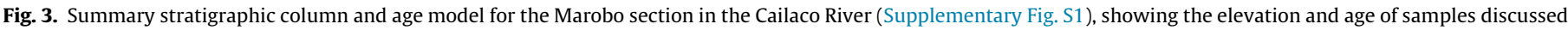
in text (CR01-CR63). Age model based on Tate et al. (2014). 

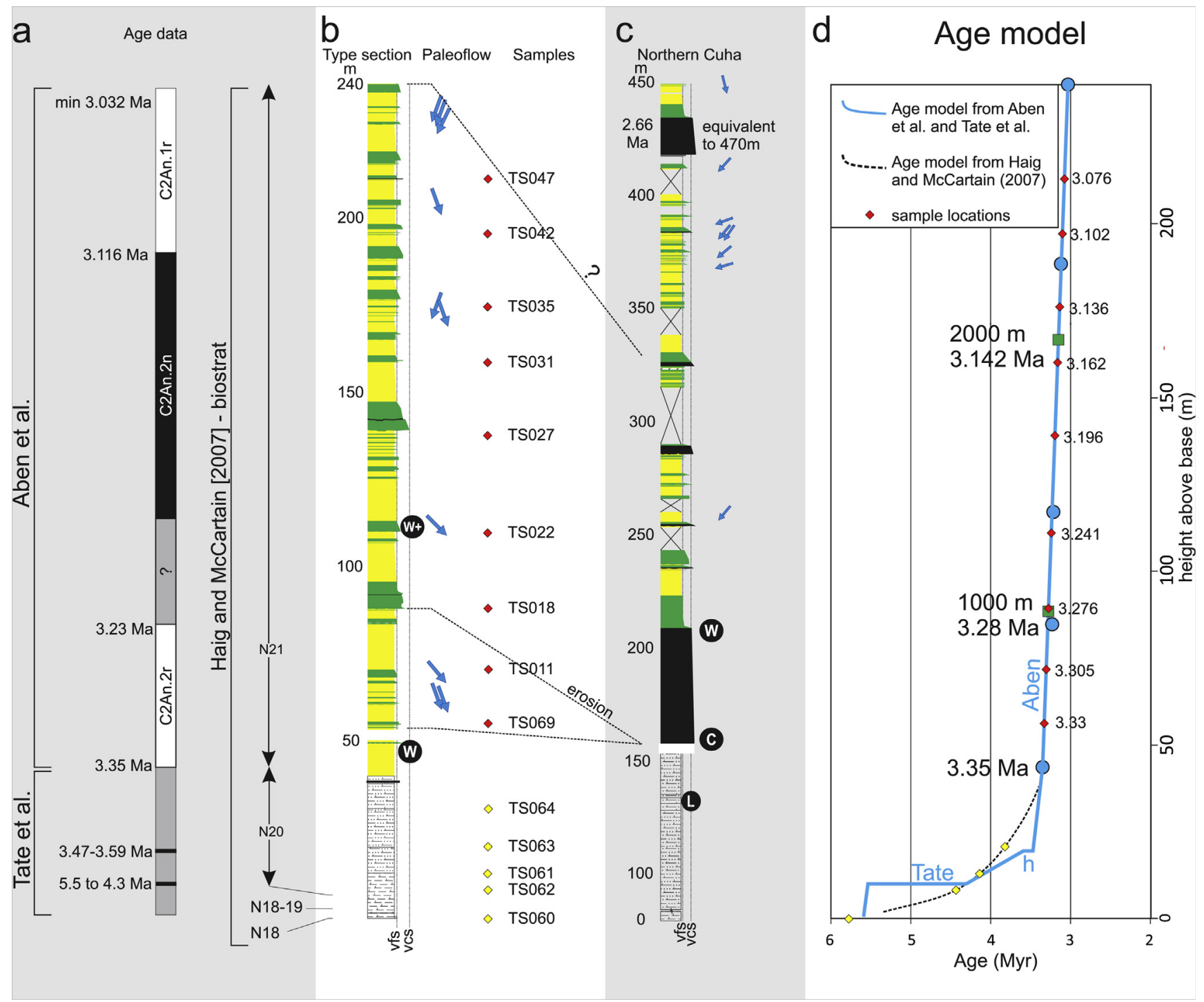

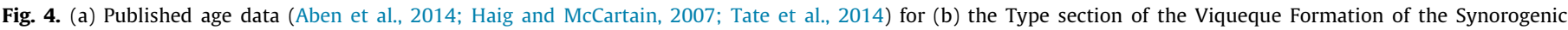

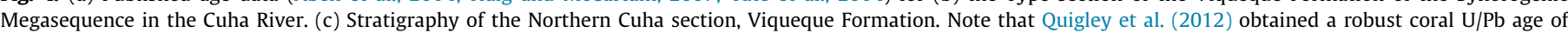
2.66 Ma for the top of the Northern Cuha section. (d) Type section age models based on data in (a).

limestone of the Batu Putih Formation that overlies the Synorogenic Mélange and incorporates mélange clasts in its lowest few centimeters. The basal limestone grades into $>40 \mathrm{~m}$ of softer, light grey to blue marls. The marls give way to the Viqueque Formation, which in the measured section consists of a variable succession of southwest to south-dipping conglomerates, pebbly sandstones, sandstones and mudstones. Many of the mudstones are subtly internally graded. Foraminifera are only common in the uppermost few $\mathrm{cm}$ of these mudstone units. Visible woody and organic detritus are rare throughout most of the section but become common in the thinly-laminated pebbly sandstones that occur in the top $50 \mathrm{~m}$ of the measured section (Fig. 3). The paleoflow directions measured in the section suggest that these sediments were emplaced toward the south and southwest (Fig. 3) but they have been subjected to a $65-70^{\circ}$ counterclockwise tectonic rotation (Aben et al., 2014) and were thus probably sourced from the east.

\subsection{Laleia basin}

The Laleia basin (Duffy et al., 2013) has not been biostratigraphically dated. A thin sliver of Batu Putih Formation on the south side of the basin is overlain by at least $270 \mathrm{~m}$ of clastic sediments that are dominated by weakly cross bedded, crudely rounded to angular, cobble conglomerates, interbedded with thin sandstones. The sample localities for the Laleia Basin are shown in Supplementary Fig. S2.

\subsection{Viqueque basin}

Two stratigraphic sections (Fig. 4b, c) were measured in the Viqueque area where the Viqueque Formation is widely exposed in the rivers and streams (Supplementary Fig. S3). Age models (Fig. 4d) follow Quigley et al. (2012, Northern Cuha) and Aben et al. (2014, Type section), and indicate that the Northern Cuha section reaches younger ages than the type section.

The Batu Putih Formation of the Viqueque area is chalkier and more weakly indurated than in the Marobo basin but otherwise similar. Bedding in the chalk and marls is generally indistinct, but becomes more distinct upsection. Audley-Charles (1968) reported the presence of two vitric tuff beds in the marls of the type section, but these were not observed. The marls thicken 
northwards in the Viqueque area, from $\sim 40 \mathrm{~m}$ at the type section to $\sim 100 \mathrm{~m}$ at the Northern Cuha section (Fig. 4b, c).

The Viqueque Formation in the type area consists of a rhythmic succession of interbedded, normally graded sandstones and massive mudstones, punctuated by thick, lensoidal conglomerates and sandstones. The conglomerates attain thicknesses in excess of $70 \mathrm{~m}$ and commonly contain aragonitic detrital coral heads; a $\mathrm{U}-\mathrm{Pb}$ age of a coral constrains the age of the top of the Northern Cuha section (Quigley et al., 2012) (Fig. 4c). Most of the paleoflow directions in Viqueque are toward the south and southwest and no tectonic rotation has been documented in the basin (Aben et al., 2014). Most conglomerates are found north of Viqueque and terminate southwards at the Viqueque fault zone. The south side of the basin, including the type section, is dominated by normally graded sandstones and massive mudstones (Fig. S3). Thick, poorly sorted sandstones there are similar in many respects to Northern Cuha conglomerates; they both exhibit a combination of inverse to normal grading and contain brecciated, finer-grained intraclasts that float some distance above the base of the bed (Duffy, 2013). Woody detritus ranging from thin laminae to entire trees is common throughout both sections, usually incorporated within or overlying thick sandstone units (Quigley et al., 2012). Massive to subtly normally graded mudstones are found interbedded throughout the succession and usually contain foraminifera mainly in the uppermost few centimeters. The thickening of mudstones that overlie poorly sorted conglomerates and sandstones indicates that they represent the tails and upper portions of those flows.

\subsection{DSDP 262}

Deep Sea Drilling Project (DSDP) hole 262 (Fig. 1a, b) is located $<1 \mathrm{~km}$ south of the axis of the Timor Trough, $\sim 50 \mathrm{~km}$ south of West Timor $\left(10^{\circ} 52^{\prime} \mathrm{S}, 123^{\circ} 51^{\prime} \mathrm{E}\right)$. Modern Timor Trough lithogenic sediments are derived from Timor (Van Andel and Veevers, 1967), and the micropaleontology of this drill core records the timing and rates of tectonic events and the bathymetric development of the Timor Trough (Johnston and Bowin, 1981; Veevers et al., 1978). The basal $28 \mathrm{~m}$ of sediments in the DSDP 262 core (Level A, Fig. 5) are shallow marine calcarenites and foraminiferal mudstones that are dolomitized and phosphatized (Cook, 1974a,b;
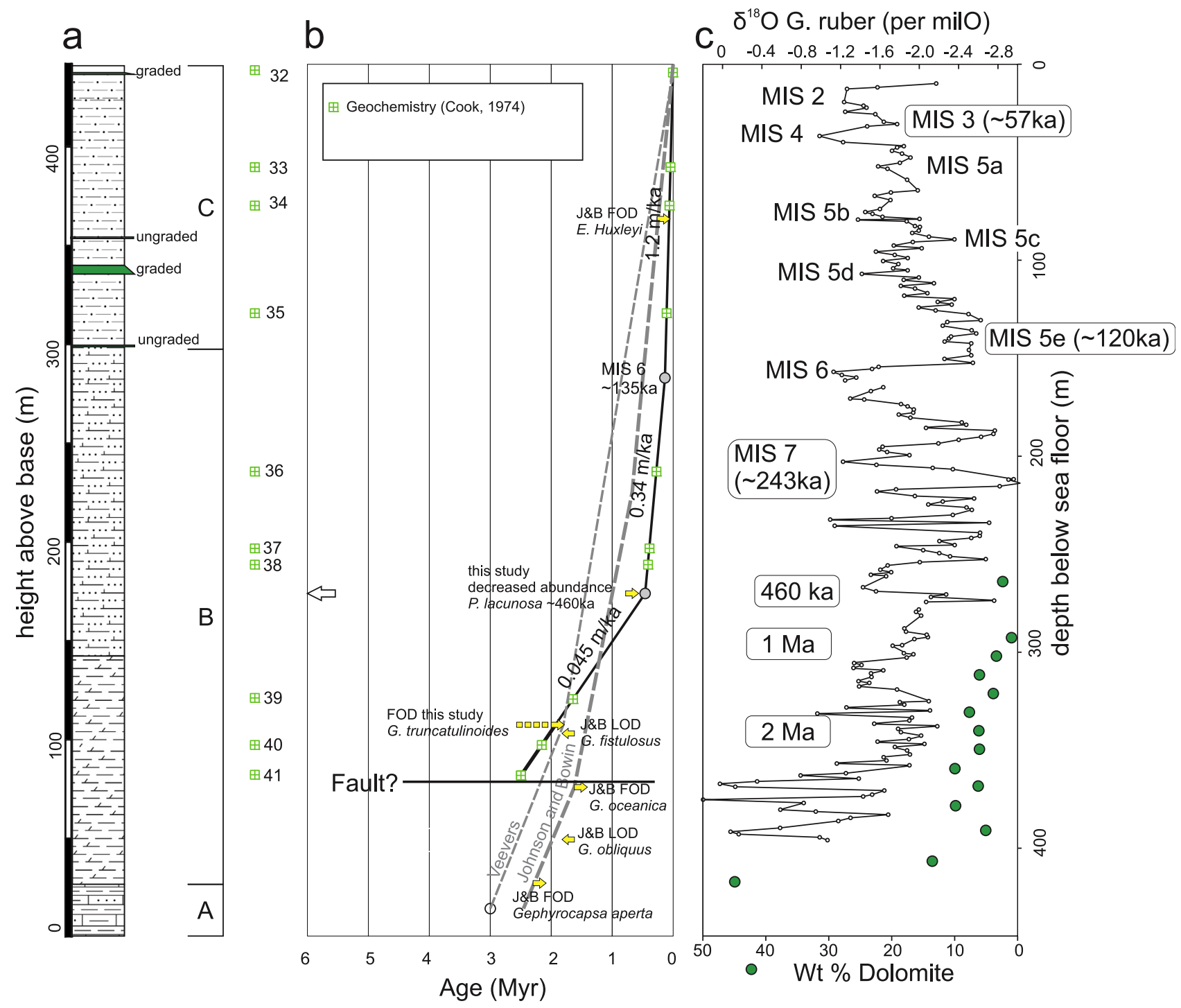

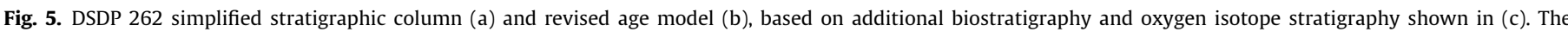

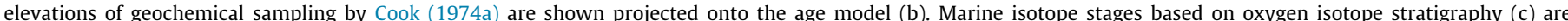

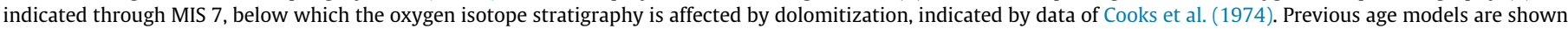
for comparison. 
Cooks et al., 1974; Heirtzler et al., 1974). These lowest sediments accumulated on the Australian shelf before the core basement was bent down into the Timor Trough (Veevers et al., 1978). They grade into bathyal ooze that accumulated in the Timor Trough (Level B, Fig. 5). This ooze is variably rich in foraminifera and radiolarians and extends until around $300 \mathrm{~m}$ above the base of the hole, where the first, ungraded, detrital foraminiferal sand layer is found (base of Level C in Fig. 5). Even within Level C, sand is of secondary importance to radiolarians and foraminifera, except for a $4.5 \mathrm{~m}$ interval of thick graded sand at $360 \mathrm{~m}$ above the base. Apart from the basal $28 \mathrm{~m}$ of the core, the remainder of the DSDP 262 core seems to be lithologically equivalent to the Batu Putih Formation, although the Batu Putih Formation was originally deposited in piggy back basins over the deeper parts of the young orogen, rather than over the deeper parts of the continental margin before underthrusting. Batu Putih-like units make up much of the upper-most sections of the Australian Continental Margin MegaSequence that is accreted at the trough to the southern part of Timor (Sawyer et al., 1993).

The DSDP 262 age model is based upon the original biostratigraphy by Heirtzler et al. (1974) and supplemented by new $\delta^{18} \mathrm{O}$ stratigraphy (Fig. 5). Johnston and Bowin's (1981) age model is shown for comparison. The $\delta^{18} \mathrm{O}$ stratigraphy constrains the age model through MIS 7, however, dolomitization of the sediments (Cooks et al., 1974) affects $\delta^{18} \mathrm{O}$ values preventing the use of $\delta^{18} \mathrm{O}$ stratigraphy below $\sim 250 \mathrm{~m}$. The $\delta^{18} \mathrm{O}$ stratigraphy shows extended interglacials with high sedimentation rates during MIS 5 $(\sim 270 \mathrm{~cm} / \mathrm{kyr})$ and MIS $7(135 \mathrm{~cm} / \mathrm{kyr})$, whereas the glacial periods are extremely condensed relative to the interglacials. Both the Holocene and stage 5e are truncated by a turbidite. Using the $\delta^{18} \mathrm{O}$ stratigraphy the $4.5 \mathrm{~m}$ graded sand occurs during MIS $5 \mathrm{~d}$ and has an age of $\sim 110 \mathrm{ka}$. The last appearance of $P$. lacunose, which is based upon decrease abundance at $\sim 270 \mathrm{~m}$ depth, corresponds to $\sim 460 \mathrm{ka}$, suggesting substantially reduced sedimentation rates below 220 mbsf. Heirtzler et al. (1974) reported the first occurrence of Globorotalia truncatulinoides at $337 \mathrm{~m}$, which is now dated at $2.58 \mathrm{Ma}$ in the SW Pacific and $1.93 \mathrm{Ma}$ in the Atlantic (Lourens et al., 2004; Wade et al., 2011).

\section{Provenance analysis}

\subsection{Conglomerate clast composition}

\subsubsection{Marobo basin}

The Marobo conglomerates are composed of dark grey sericite schist (30-63\%), quartz (0.5-10\%) and feldspar (4-22\%), supplemented by small but regular amounts of intraformational sandstone $(0-10 \%)$, quartzite $(0-6 \%)$, calcareous schist $(0-6 \%)$ and epidote schist $(0-3 \%)$. Rare chloritoid schist clasts are present at the base of the section, along with a single occurrence of four igneous clasts in a sample from the base of the clastic part of the section (65 m - CR24a). The sericite schist clasts are commonly mylonitized such that the quartz grains show a preferred orientation under a gypsum plate and are elongate at around a $10^{\circ}$ angle to the mica schistosity. Several clasts from the top of the section (e.g., Cr62a - Fig. 3) contained rounded zircon and relict feldspar grains in a matrix of fibrous quartz and sericite.

Calcite cemented samples, such as CR24a, were thin sectioned intact and contain up to $10 \%$ of intraformational sandstone clasts eroded from pre-existing synorogenic sandstone beds. This is in keeping with the common occurrence of floating layers of sandstone and mudstone clasts, even from the base of the section, and suggests significant reworking of older synorogenic sediments, either uplifted or sourced from channel wall collapse. The importance of extraformational, indurated, quartzofeldspathic sandstone clasts increases up section from $\sim 250 \mathrm{~m}$ above base (a.b.) (CR41a) and an influx of indurated mudstone clasts occurs above $\sim 350 \mathrm{~m}$ a. b. (CR49a) in the upper half of the section. Limestone clasts only occur above $\sim 480 \mathrm{~m}$ a.b. (CR56a), near the top of the section.

The clast composition of the Marobo Basin conglomerates suggests erosion of an evolved, (continental type?) weakly metamorphosed, highly strained source. Sandstone intraclasts occur throughout but a source for un-metamorphosed, indurated sandstones and limestones is progressively exposed.

\subsubsection{Laleia basin}

Three samples were examined from the Laleia Basin (La 587, 557 and 592). Their locations are indicated in Supplementary Fig. S2. A wide variety of limestones contribute $6-8 \%$ of the clast content. Sandstones contributed $9-20 \%$ of the conglomerate clasts but no clear trends were observed. Quartz clast content increases upsection from 8 to $21 \%$. Amphibolite clasts declined in importance upsection, from 24 to $1.3 \%$. A diverse assemblage of schists maintained a $30-40 \%$ contribution to clasts throughout all three samples. Igneous rocks contribute $3-12 \%$ of the clasts.

Limestone clasts are common throughout the studied Laleia conglomerates. The middle conglomerate (La557) contained a particularly diverse assemblage of limestone clasts. Distinctive lithologies included hornblende and serpentinite-bearing limestones (serpentinite also occurred separately), as well as calcilutites containing silicified fusulinids and unsilicified fusulinids and crinoids. The association of silicified fusulinids and crinoids is characteristic of the Permian Maubisse Formation of the Gondwanan Megasequence (Barkham, 1993; Charlton et al., 2002). Silicification is characteristic of Paleozoic fossil assemblages in general (Schubert et al., 1997).

The metamorphic clasts of the Laleia Basin are completely distinct from those of the Marobo Basin. The basal conglomerate contains abundant clasts of epidote and chlorite rich amphibolites, amphibole schists, and epidote and chlorite schists. Many of the amphibolite clasts have a strong mylonitic fabric. There is also abundant evidence of hydrothermal activity in the source area for the metamorphic clasts. An epidote amphibolite clast in the middle conglomerate (La557) was cut by a quartz vein that was in turn crosscut by a calcite vein, whereas another vein in the same clast contained hydrothermal chloritoid. Though uncommon, hydrothermal chloritoid has been reported from metasomatized mafic igneous complexes in India and Australia (Gustafson, 1946; Halferdahl, 1961; Prider, 1947; Venkatesh and Malhotra, 1960).

Dacite, granophyre and peridotite clasts were identified in the basal sample (La587). These included several fresh I-type trachydacite clasts. One of these clasts (La587a) initially contained a peridotite xenolith that fell out during thin sectioning, and also a dacite xenolith of comparable mineralogy to the host rock. The La587a dacite clast is composed of $<85 \%$ low-albite, together with abundant magnetite, minor amphibole, interstitial chlorite and quartz, and up to $5 \%$ granophyre. Granophyre was also present as a discrete clast in the same sample, and may have been sourced from a dacitic rock. Another dacite clast contained titanite, suggesting that these were derived from oxidised magmas. No further dacite clasts were observed upsection, and the volcanic clasts higher in the section were mainly spherulitc and porphyritic basalts, dolerites and altered igneous rocks, suggesting an unroofing sequence of dacites capping basalts and dolerites.

\subsubsection{Viqueque basin}

The basal conglomerate of the Northern Cuha section (LM19) has eroded deeply, entraining large amounts of pre-existing strata and is not considered as representative of the basal stratigraphy as the thinner turbidites at the base of the type section (Supplementary Table S3; Fig. 4). Therefore, point counts were made of seven 
type section sandstones and four conglomerate samples from the Viqueque area. The locations of the samples are indicated in Fig. S3. Limestones increase their contributions from 1.5-1.9\% of the lithics in the sandstones at the base of the type section, to $15-22 \%$ of the clasts in the conglomerates at the top of the section. Quartz content ranges up to $58 \%$ in the finer grained sandstones at the base of the section but is otherwise typically $5-15 \%$ of clasts in the conglomerates. In contrast, the type section's fine grained sandstones (TS070-TS017) contain virtually no igneous material, which provides $5-12 \%$ of the conglomerate clasts. LM19 contains abundant peridotite clasts. Amphibolites contribute $5-26 \%$ of the conglomerate clasts, whereas the sandstones typically contain 6$20 \%$ amphibole crystals. Upwards of $5 \%$ of the amphibolite clasts in the Viqueque conglomerates are mylonitized and they mostly contain albite with bent deformation twin lamellae. Several amphibolite clasts contained stout crystals of clear to pale green amphibole with a preferred orientation that were surrounded and intruded by tremolitic amphibole with a different preferred orientation. Three clasts of schist in LM19 contained chlorite and serpentine with rotated clinopyroxene porphyroclasts. Chlorite schist clasts or grains decline in importance upsection from $16 \%$ at the base of the Viqueque Formation to between 2 and $4.7 \%$ at the top of the Viqueque Formation. Total schist remains constant, however, as clasts of chlorite schist are replaced by clasts of chlorite/sericite and sericite schist. Quartz mylonite clasts appear at the top of the Northern Cuha section in association with the influx of sericite schists.

The first igneous material in the type section appears at about $86 \mathrm{~m}$ a.b. (TS018). Clasts consist of a mixture of diorite, dolerite, peridotite and spherulitic basalt. The composition is petrographically similar to the igneous material in the conglomerate at the base of the Viqueque Formation in the Northern Cuha section (LM19), apart from the peridotite-rich nature of the coarser LM19, although abundant peridotite was observed in the uncounted sandstone TS019 immediately above TS018. In addition, both LM19 and TS018 contain partly silicified and chloritized limestone clasts, which are not seen lower in the type section. These are characteristic of the Permian Maubisse Formation of the Gondwana Megasequence. TS018a and LM19 also contain similar percentages of sheared/mylonitized amphibolite clasts and do not contain the chlorite and chloritoid species of amphibolite that appear higher in the section. TS018a contains the greatest concentrations of amphibolite in the sandstones, and LM19 contains the greatest concentrations in the conglomerates. These characteristics suggest that TS018 and LM19 are correlative. TS030 contains the only granophyre noted in this section.

The clastic sediments contain variable amounts of carbonate material. The conglomerates typically contain $\sim 2 \%$ of shallow water carbonate detritus such as Platygyra and Goniastrea corals, and gastropod shells. The coral heads are generally well preserved and aragonitic (Quigley et al., 2012). Most carbonate detritus is concentrated within the sandstone lithologies, which contain 5$50 \%$ of comminuted shelly detritus and foraminifera. The concentration and preservation of carbonate detritus correlates negatively with grainsize within the sandstone lithologies. Intact foraminifera are generally found only in the plastic mudstones that form the top of individual fining-up packages and are erosionally truncated by the sandstone beds.

The association of chlorite and serpentine schist with rotated clinopyroxene porphyroclasts, is reported from the Jandaq ophiolite in Iran (Torabi et al., 2011), and is suggestive of a source terrane that includes meta-lherzolites such as the Hili Manu lherzolite of Timor (Berry, 1981; Harris, 1992; Harris and Long, 2000). The mylonitization of amphibolites is a common feature of both the Aileu Complex and the Banda Terrane of West Timor (de Roever, 1940; Ishikawa et al., 2007). In the Banda Terrane it is commonly observed in association with granitic bodies formed during anatexis, possibly accounting for both the granophyre (Helmers et al., 1989) and the cordierite veining (e.g., Linthout et al., 1997). Deformation twinning of albite such as occurs in the amphibolites is not considered to occur below $500{ }^{\circ} \mathrm{C}$ (Gapais, 1989; Tullis, 1983; Voll, 1976) and is consistent with high temperature metamorphism of the protolith. The widespread occurrence of tremolitic amphibole indicates that the source rocks underwent retrogression following high temperature metamorphism.

In summary, the three sections have different clastic provenance, with the Marobo section derived predominantly from Banda metapelites, the Viqueque section containing abundant Banda metabasites and the Laleia section containing predominantly Banda cover rocks. However, there is some ambiguity due to similar metamorphic rocks also occurring in the Aileu complex. Without geochemical or age data it is difficult to know which metamorphic complex they are derived from.

\subsection{Geochemical provenance}

Major, trace and rare earth element geochemistry were used to provide constraints on sedimentary provenance based on a variety of tectonic discrimination diagrams that are available (Bhatia and Crook, 1986; Hiscott, 1984; McLennan, 1989; McLennan et al., 1993; Roser and Korsch, 1988; Taylor and McLennan, 1985) and on source area weathering based on the chemical index of alteration (Fedo et al., 1995; Nesbitt and Young, 1989; Nesbitt et al., 1996). This section presents evidence for changing rates of terrigenous sediment supply and the changing relative contributions to sedimentation from carbonate, Australian shale, Banda Terrane forearc, Gondwanan and volcanic arc sources. Major and trace element geochemistry of the synorogenic sections is reported in Supplementary Table S4 (Marobo) and Table S5 (Viqueque). Conglomerate clast chemistry is reported in Table S6, synorogenic $\mathrm{Sm} / \mathrm{Nd}$ geochemistry in Table S7, and the Sm/Nd geochemistry of float clasts in Table S8.

The overall lithological and geochemical character of synorogenic sediments reflects progressive dilution of carbonate sediments with lithogenic sediments during the early Pliocene. Plots of $\mathrm{CaO}$ (as a proxy for carbonate - Fig. 6) against major and trace elements (reflecting lithogenic input) for fine grained sediments, including those from DSDP 262 (Cook, 1974a) show a strong negative covariance of major oxides (except $\mathrm{P}_{2} \mathrm{O}_{5}$ ) and trace elements (except $\mathrm{Sr}$ ) with $\mathrm{CaO}$. $\mathrm{Al}_{2} \mathrm{O}_{3}$, a proxy for terrigenous sediment, shows the most linear negative correlation with $\mathrm{CaO}$ (Fig. 6a). The rocks of the Batu Putih Formation are similar in many respects to the DSDP 262 core samples, but DSDP262 commonly has elevated $\mathrm{MgO}$ and $\mathrm{NaO}$. This may reflect the relative importance of clay species. The Marobo and Viqueque mudstone samples all have $<5 \%$ clay minerals, all kaolinite, whereas the DSDP samples have $<13 \%$ montmorillonite and $<5 \%$ kaolinite (Cooks et al., 1974), substantially similar to the mineralogy reported for Synorogenic Mélange in the Bobonaro area by Audley-Charles (1965). Montmorillonite is enriched in sodium and magnesium, compared with kaolinite. Other differences between DSDP 262 and Batu Putih rocks are consistent with differences in the relative importance of biogenic and diagenetic influences. For instance, the positive correlation of $\mathrm{Sr}$ with $\mathrm{CaO}$ is probably biologically controlled in both Batu Putih and DSDP 262 samples. Similarly, high $\mathrm{SiO}_{2} /$ $\mathrm{Al}_{2} \mathrm{O}_{3}$ ratios in the DSDP 262 samples probably reflect the more radiolarian rich sediments in the DSDP core (Heirtzler et al., 1974) compared with foraminiferal sediments on Timor. Diagenetic dolomitization of the DSDP samples (Fig. 5) also leads to enrichment in $\mathrm{Mg}$ (Cooks et al., 1974). The dolomitized calcarenites from the base of DSDP 262 also have elevated $\mathrm{P}_{2} \mathrm{O}_{5} / \mathrm{Al}_{2} \mathrm{O}_{3}$ ratios, which Cook (1974b) interpreted as diagenetic phosphatization that 


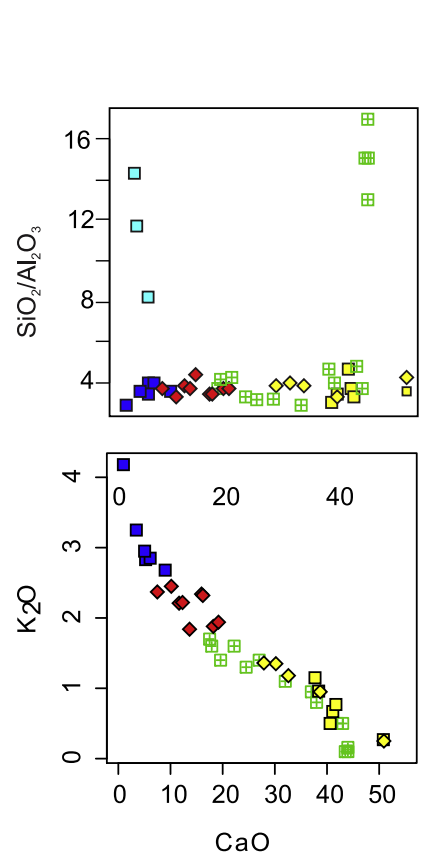

$\diamond \quad$ Vqq type section carbonate

$\diamond$ Vqq type section mudstone
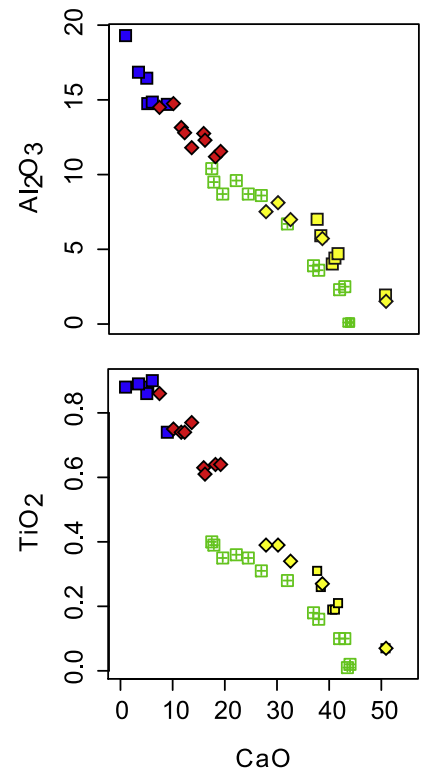

b: Trace elements
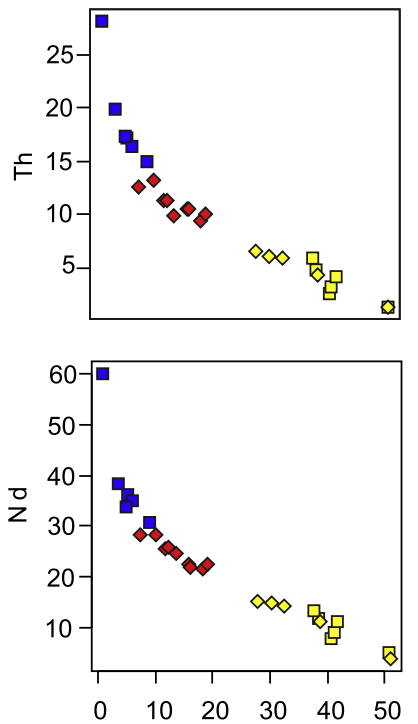

$\mathrm{CaO}$
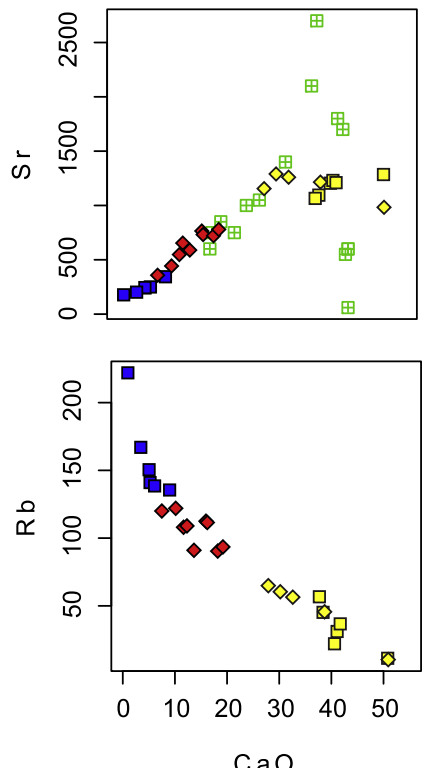

$\square \quad$ Marobo section carbonate

- Marobo section mudstone

․ Marobo section sandstone
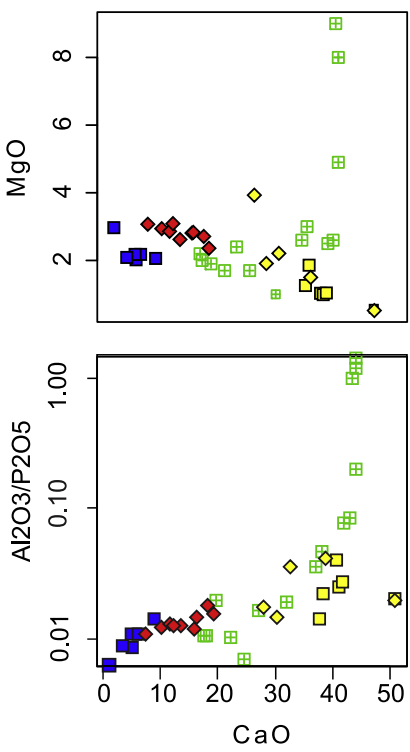

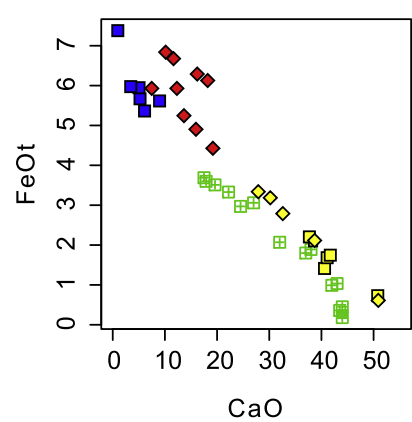

$\boxplus \quad$ DSDP $262($ Cook, 1974)

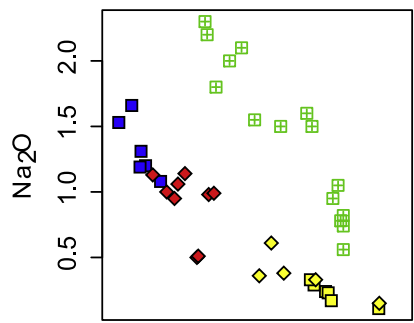

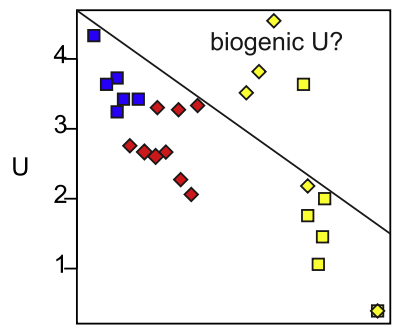
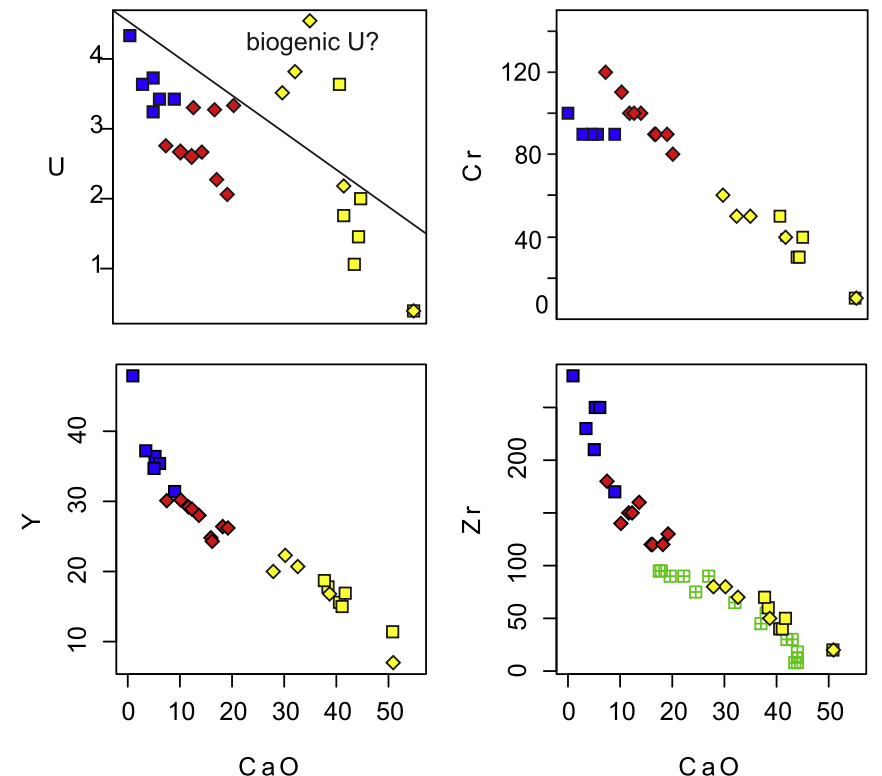

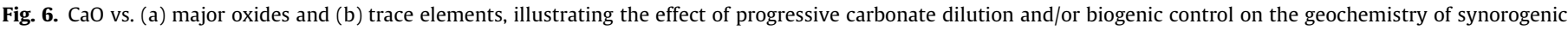
carbonates, marls and mudstones of the Viqueque and Marobo sections (this study) and DSDP 262 (Cook, 1974a).

occurred in association with dolomitization. The Viqueque mudstones are more calcareous and have higher phosphate concentrations than do the Marobo mudstones.

\subsubsection{Major element geochemistry}

A trend of increasing lithogenic contribution to synorogenic sediments is directly related to documented uplift and exhumation events (Fig. 7). In general, $\mathrm{CaO}$ concentrations decline and $\mathrm{LOI}_{550}$ increases upsection. These trends are correlated with the early stages of subaerial surface uplift (Fig. 7c) (Nguyen et al., 2013). $\mathrm{Al}_{2} \mathrm{O}_{3}$ concentrations also increase upsection (Fig. 7d). Both the Marobo and Viqueque sections show the same slow but steady increase in terrigenous sedimentation within the carbonate sediments, followed by a distinct jump associated with the onset of clastic sedimentation and rapid uplift. The $\mathrm{Al}_{2} \mathrm{O}_{3}$ concentration in the DSDP 262 core exhibits the same patterns and rates of change, but lags the Timor-Leste sections by $\sim 3 \mathrm{Myr}$ (Fig. 7c\&d). Although the $\mathrm{Al}_{2} \mathrm{O}_{3}$ concentrations in the DSDP 262 samples remains low, the change in the rate of terrigenous sedimentation coincides with the first sandy layer that marks the start of Level C of the DSDP 262 core (Fig. 5), and corresponds closely to the onset of rapid uplift proposed for the Central Basin of West Timor by van Marle (1991) (Fig. 7c). However, a recent re-evaluation of van Marle's Sabau section found it to be much older throughout, and with paleobathymetry that does not require a late uplift pulse (Tate, 2014). Tate's data can be fitted to uplift rates of $\sim 0.67 \pm 0.13 \mathrm{~mm} / \mathrm{yr}$, indistinguishable from the earliest Pliocene (pre-main phase) surface uplift rates estimated for East Timor by Nguyen et al. (2013). 


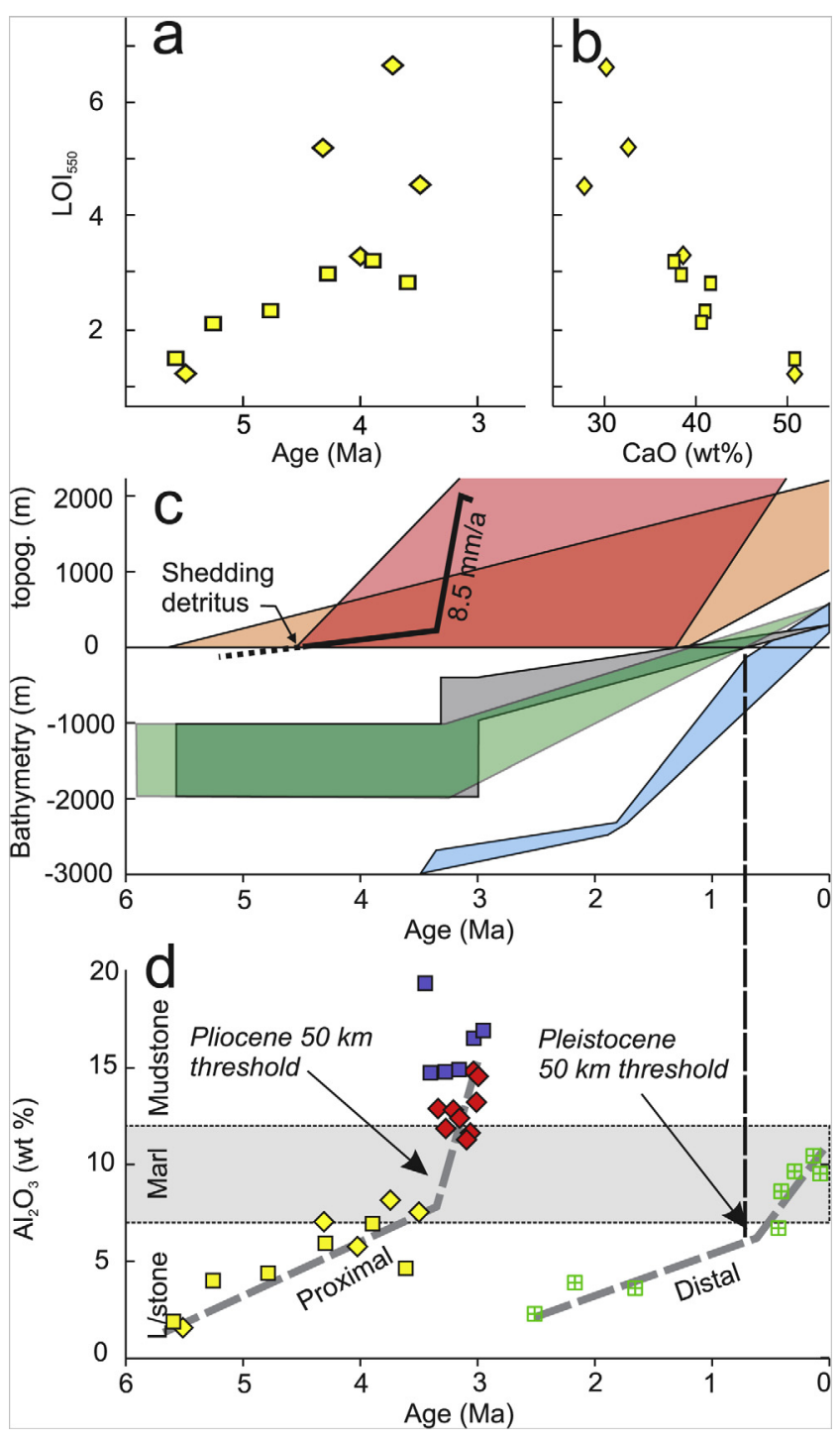

Fig. 7. Relationship of geochemistry to age, and exhumation and uplift rates. Legend as Fig. 6. Parts a, $\mathrm{c}$ and d share a common time scale (x axis). (a) LOI550 (organic material content) increases throughout the Early Pliocene in both the Viqueque and Marobo sections, and is matched (b) by a decline in $\mathrm{CaO}$ due to increasing marliness. A geohistory diagram (c) shows uplift rates for the Viqueque type section (heavy black line; revised from Nguyen et al. (2013) based on magnetostratigraphy of Aben et al. (2014)). The exhumation history is shown for the central and western Aileu (Red polygon) and the apatite-helium region of the south coast of Timor-Leste (orange polygon) (both from Tate et al., 2014); The uplift histories of the synorogenic Sabau section of the Central basin of West Timor (green polygon) and the Viqueque type section (grey polygon) are from Tate (2014) and Tate et al. (2014), respectively. The blue polygon envelopes the uplift data for synorogenic sections in Savu and Rote (Roosmawati and Harris, 2009). (d) Shows $\mathrm{Al}_{2} \mathrm{O}_{3}$ concentrations plotted against sample age for the Timor-Leste sections and the DSDP core. Carbonate, marl and mudstone fields are based on the relationship between $\mathrm{CaO}$ and $\mathrm{Al}_{2} \mathrm{O}_{3}$ shown in $\mathrm{A}$, with marl corresponding to approximate $\mathrm{CaO}$ percentages of 24-37\%. Exhumed and DSDP 262 sections both follow the same general trend but concentrations in the DSDP 262 core begin increasing $\sim 2.8 \mathrm{Myr}$ later than in Timor-Leste, just as the Central and Viqueque Basins are projected to have become emergent. (For interpretation of the references to color in this figure legend, the reader is referred to the web version of this article.)

Major element discriminant functions provide insight into the bulk provenance of mudstone suites (Roser and Korsch, 1988). Fig. 8 compares synorogenic carbonates and mudstones with published whole rock geochemistry of volcanic and metamorphic rocks from Timor, the volcanic arc, Post Archaean Australian Shale (PAAS), Aileu and Babulu Triassic shales from Timor (generally con- sidered to be a major source of mélange) and new data from the Synorogenic Mélange. The Batu Putih carbonates from the Viqueque and Marobo sections evolve from the Mg-rich field - occupied by diagenetically dolomitized DSDP262 rocks (Fig. 8a), toward a more intermediate composition characteristic of Synorogenic Mélange and Babulu shales, and similar to average Banda Metapelites (Fig. 8b). The synorogenic samples, particularly those from the Batu Putih Formation, do not overlap significantly in major element composition with volcanic arc rocks from Atauro and Wetar, which have higher F1 values.

\subsubsection{Trace and rare earth element geochemistry}

Nickel and Chromium are taken up by early crystallized mafic phases ( $\mathrm{Ni}$ in Olivine and $\mathrm{Cr}$ in spinel, diopside and augite) so their sedimentary concentrations provide useful indicators of mafic/ ultramafic provenance (e.g., Hiscott, 1984). Yttrium and Vanadium concentrations are generally elevated in felsic rocks and felsicderived sediments. Sediments derived from a proximal rhyodacitic arc (Ely et al., 2011; Herrington et al., 2011), would therefore have high Y/Ni ratios and low $\mathrm{Cr} / \mathrm{V}$ ratios due to the lower concentrations of ferromagnesian minerals and higher concentrations of HREE. Conversely, Banda Terrane rocks should show great variability parallel to the $\mathrm{Cr} / \mathrm{V}$ axis. The $\mathrm{Y} / \mathrm{Ni}$ ratios of the Batu Putih rocks from both the Viqueque and Marobo sections become lower (more mafic) through time (Fig. 9a \& b). The youngest Batu Putih rocks and the Viqueque mudstones have trace element ratios similar to the value of Synorogenic Mélange. In the Marobo section, the $\mathrm{Y} / \mathrm{Ni}$ ratios jump abruptly with the onset of clastic sedimentation and remain at relatively felsic values of $0.75-1.2$. All synorogenic rocks have $\mathrm{Y} / \mathrm{Ni}$ ratios that are an order of magnitude lower than the arc rocks from Atauro and Wetar, and there is no $\mathrm{Cr}$ enrichment trend in the mudstones, which would be expected if unroofing of the Banda Terrane forearc had been important contributor of fine-grained sediment. In contrast, the Viqueque sandstones, which are petrographically more mafic than Marobo sandstones, show a small but clear $\mathrm{Cr}$ enrichment relative to all other synorogenic rocks.

Winchester and Floyd's (1977) discrimination scheme, based on the immobile trace element ratios $\mathrm{Zr} / \mathrm{TiO} 2$ and $\mathrm{Nb} / \mathrm{Y}$, may discriminate precursor lithology (Fig. 9c). The carbonate and Viqueque samples evolve from borderline dacite/rhyolite to basaltic andesite precursor ratios (Fig. 9c\&d) that are consistent with Synorogenic Mélange and Babulu Formation shales. As seen previously, the Marobo mudstones are more felsic than the Viqueque mudstones but still have an intermediate composition. Overall, Fig. 9 shows that the synorogenic mudstones are similar to PAAS (which has a bulk intermediate composition - Taylor and McLennan, 1985) and to the Synorogenic Mélange, which is derived from Australian-affinity rocks (Barber et al., 1986; Harris et al., 1998).

Fig. 10a explores this relationship further using a multi-element plot of trace elements normalized to PAAS. The ferromagnesian trace elements are slightly depleted in the Marobo section. With the exception of biologically enriched $\mathrm{Sr}$, the Large Ion Lithophile Elements (LILE) are depleted in both sections but more so in the Viqueque section. High Field Strength Elements (HFSE) are enriched in the Marobo section and slightly depleted in the Viqueque section. The carbonate and mélange samples have an almost exactly opposite sense of LILE and HFSE anomalies, and the mudstones (particularly the Viqueque mudstones), which are quite flat relative to PAAS, appear to represent a mix between carbonate and mélange-like components. The strength of the relationship between the carbonates and mudstones is emphasized by the correlation plots in Fig. 10b. The ratio of the ferromagnesian and HFSE trace elements shows a continuous trend between the Batu Putih Formation and the Viqueque mudstones that represents a mixing between mélange and carbonate sediment. The Marobo mudstones 


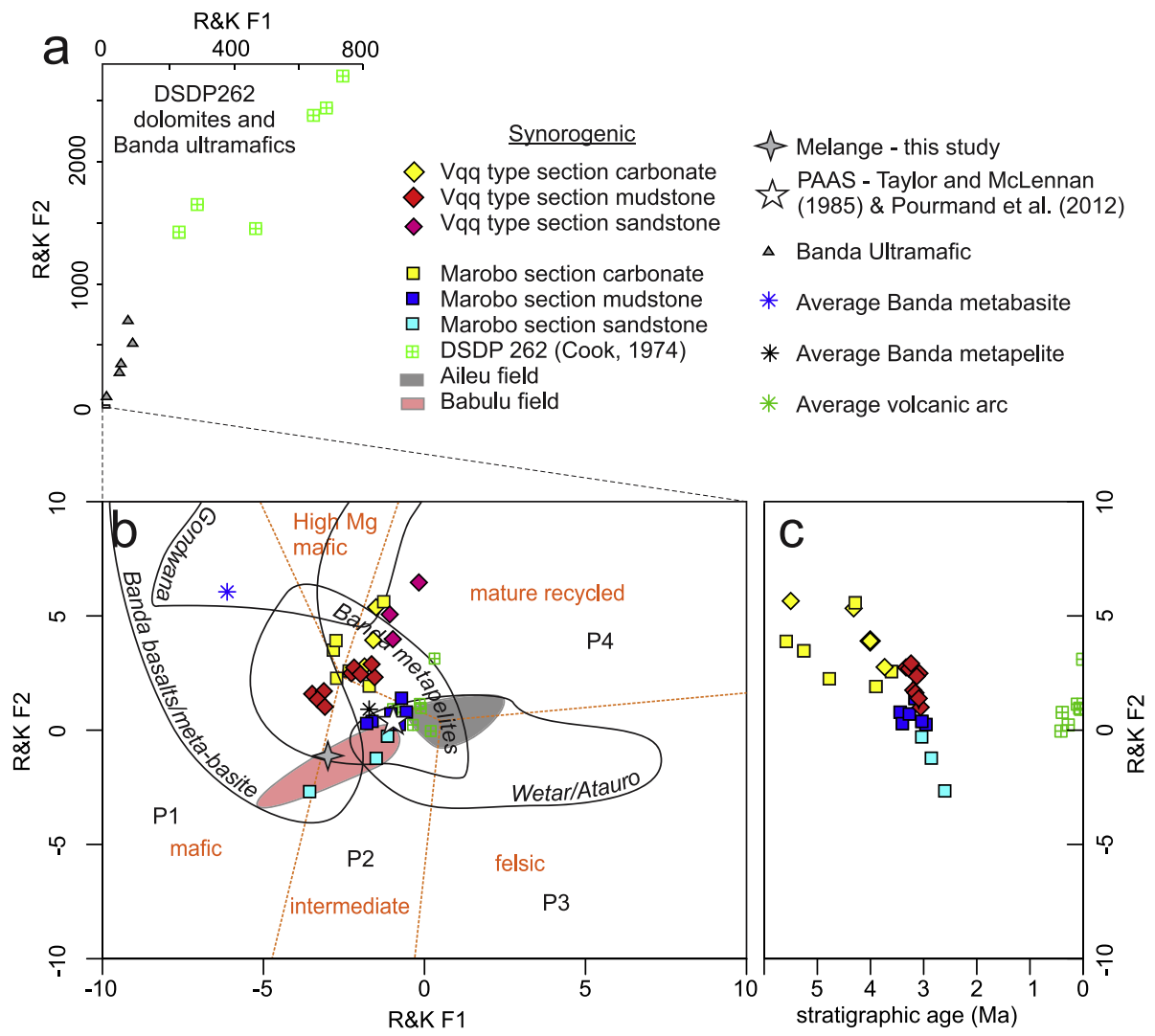

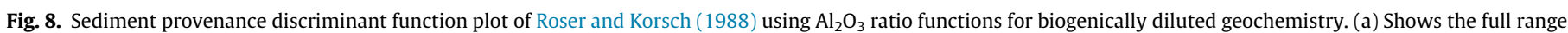

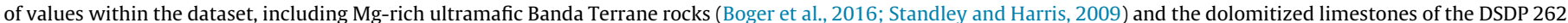

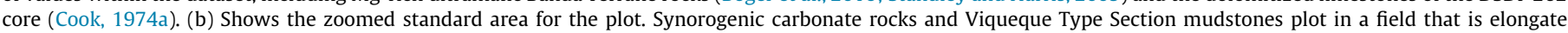

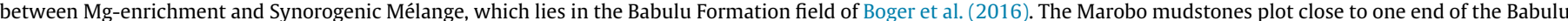

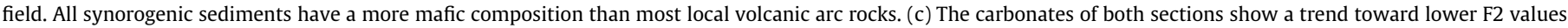
and converge on the type section mudstone field.
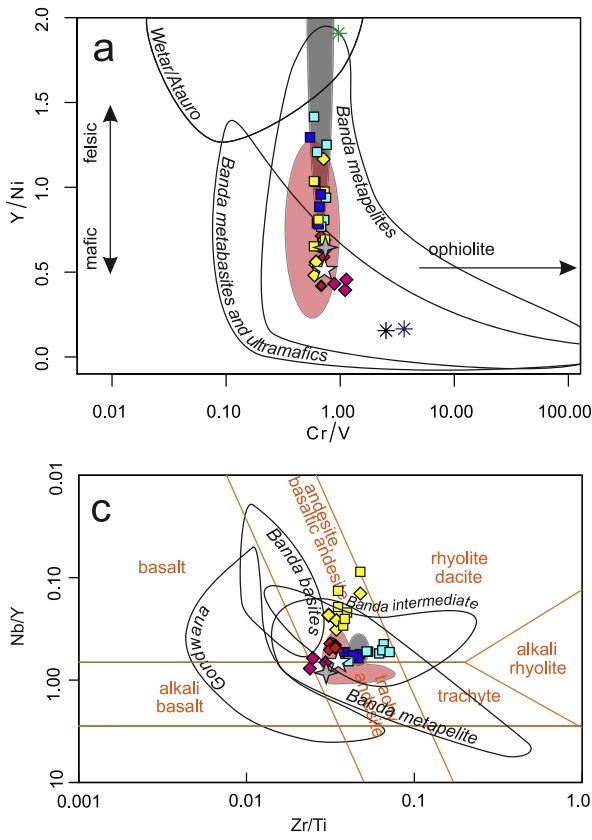
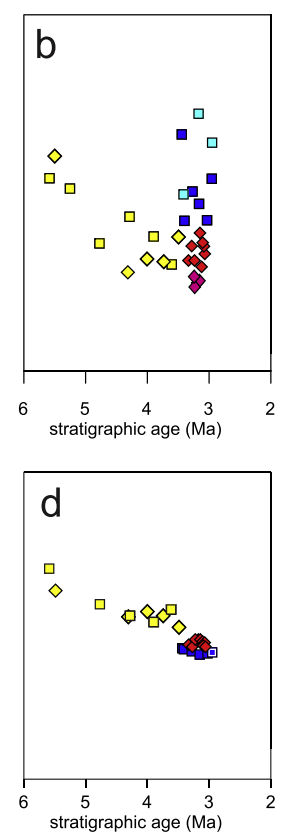

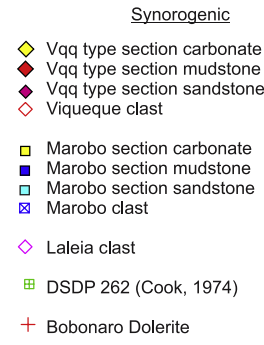

$\uparrow$ Melange - this study

PAAS - Taylor and McLennan

(1985) \& Pourmand et al. (2012)

- Aileu field

Babulu field

$\Delta$ Banda Ultramafic

* Average Banda metabasite

* Average Banda metapelite

* Average volcanic arc

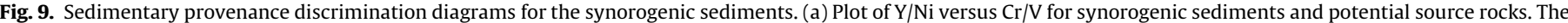

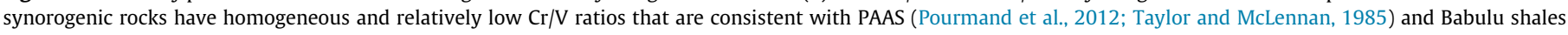

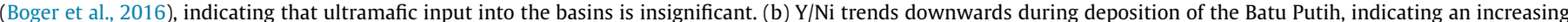

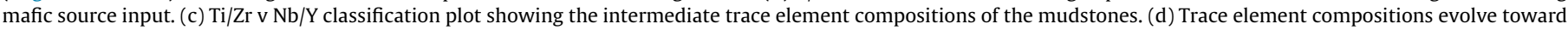
decreasing Y during deposition of the Batu Putih carbonates. 

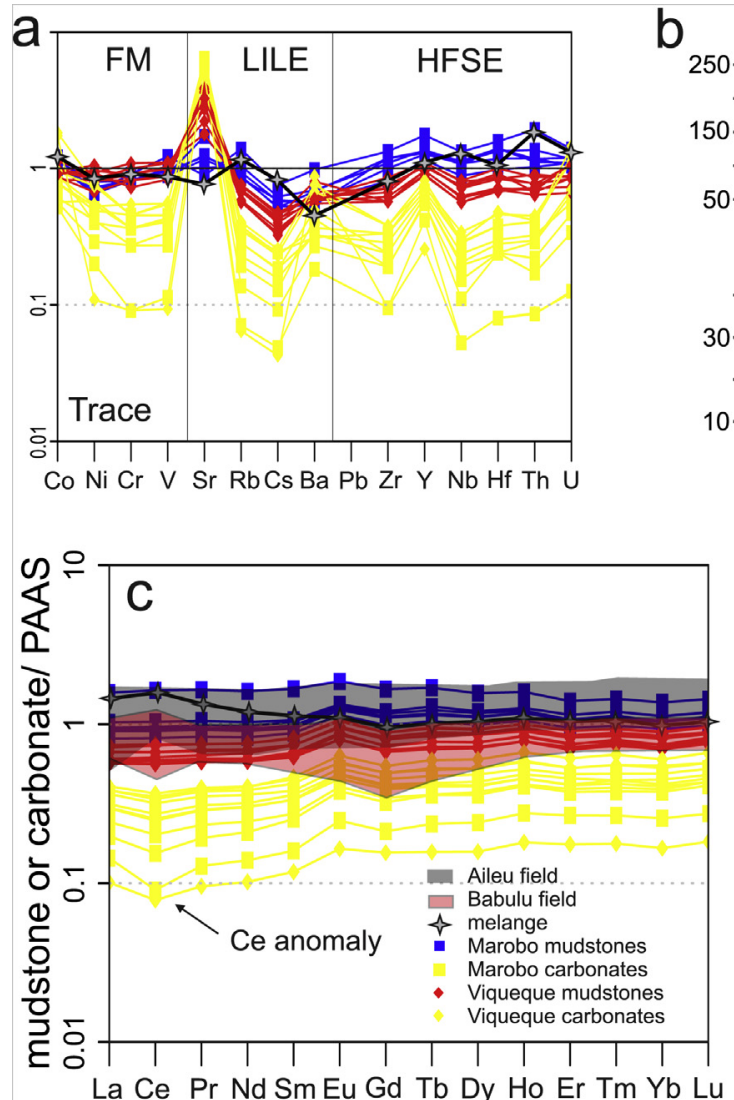

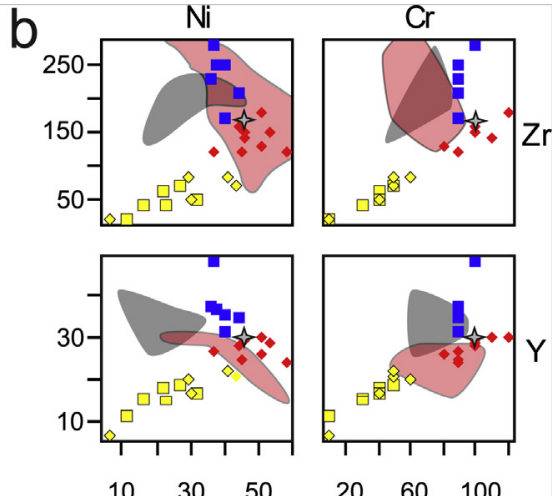

$20 \quad 60 \quad 100$

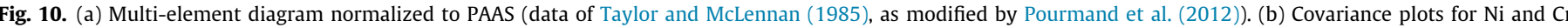

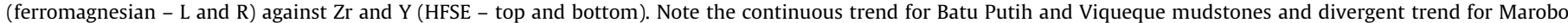

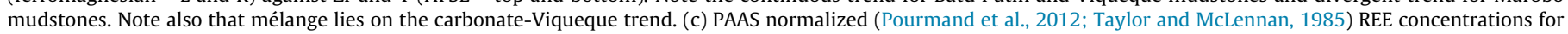
mudstone and carbonate samples. (d) Temporal trend in the Ce anomaly.

show a trend of HFSE enrichment that is negatively correlated with $\mathrm{Ni}$ and is also is seen in the Babulu Formation (Boger et al., 2016).

The REE are well suited to studying sedimentary provenance because of their relatively short residence time in ocean water and their immobility during weathering, transport, diagenesis and metamorphism (McLennan, 1989). The synorogenic carbonates and mudstones show flat REE profiles relative to PAAS (Fig. 10c). The PAAS-normalized REE concentrations are all $<1$ for the Batu Putih carbonates and the Viqueque mudstones, and $>1$ for the Marobo mudstones. Concentrations of REE are greater in mudstone than carbonates because the REE are bound in the clay structure (McLennan, 1989). As for trace elements, the carbonate and mélange samples have an almost exactly opposite sense of LREE anomalies, and the REE profiles of the Viqueque mudstones in particular appear to represent a mix between mélange and carbonate components. All mudstone samples fall within the fields of Triassic shale REE concentrations reported by Boger et al. (2016).

The carbonates show a negative Ce anomaly relative to PAAS (Fig. 10c). The Cerium anomaly $\mathrm{Ce} / \mathrm{Ce}^{*}$ (normalized Ce values that lie below or above a straight line interpolation between La and Pr) may be affected by seafloor redox conditions, diagenesis and proximity to terrigenous sources (Liu et al., 1988; Murray et al., 1991; Shields and Stille, 2001). All the carbonate samples reported here show a small negative Ce anomaly relative to PAAS. The anomaly becomes less negative upwards through the section and is positively correlated with $\mathrm{Al}_{2} \mathrm{O}_{3}$ (and negatively correlated with $\mathrm{CaO}$ ). This, together with the positive $\mathrm{Ce}$ anomaly of the mélange, suggests that in this instance the Ce anomaly becomes less nega- tive due to an encroaching sediment source rather than a change in seafloor redox conditions. Nevertheless, the Ce anomaly at the base of the Batu Putih Formation, together with low U concentrations (0.38-0.39 ppm) and low U/Th ratios (0.3-0.31), are consistent with an oxic sedimentary environment in the Banda forearc region during the latest Miocene (e.g., Liu et al., 1988).

\subsubsection{Samarium/neodymium isotope chemistry of synorogenic sediments}

Samarium fractionates from neodymium during the melting of mantle and formation of continental crust, producing significant isotopic variations through time. The Sm-Nd chemistry of sediments therefore reflects the mean age of mantle extraction of the rare-earth-element component of the sediment source (McCulloch and Wasserburg, 1978). Sm and Nd isotopes were analyzed for sandstone and mudstone samples from the base, middle and top of the Viqueque Formation in the Marobo and Viqueque Basins, and for a mélange sample. Carbonate rocks were excluded because epsilon neodymium $(\varepsilon N d)$ of seawater varies independently of hemipelagic sediment inputs to seawater (Jones et al., 1994) and controls the $\varepsilon N d$ of foraminifera in the water column (Vance et al., 2004). Sea water $\varepsilon N d$ ranged between -4 and -6.6 in the Plio-Quaternary Indonesian Throughflow (Gourlan et al., 2008; Martin and Scher, 2006).

Fig. 11a plots $\varepsilon N d$ (the most reliable indicator of provenance age - Ehrenberg and Nadeau, 2002) against Th/Sc ratios (indicative of bulk composition). This plot differentiates between old evolved crust in the bottom right of the plot and young arc sources in the 


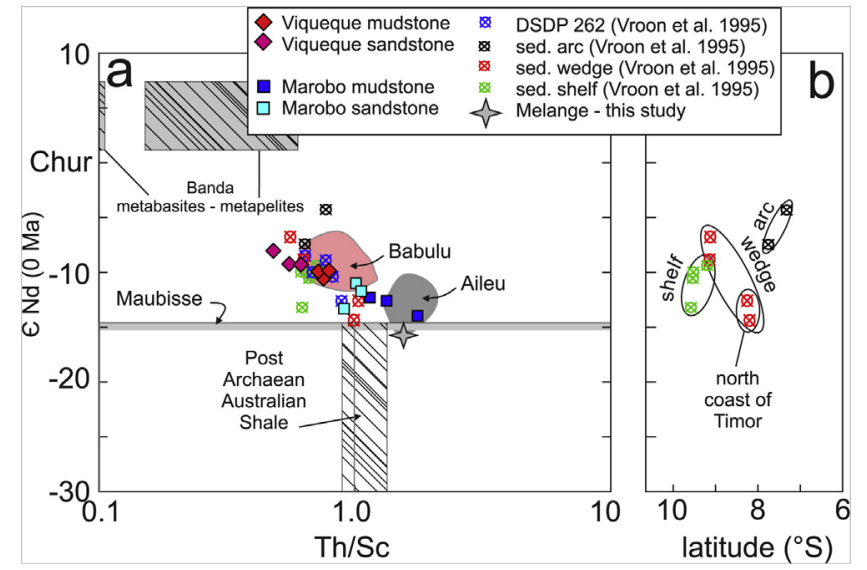

Fig. 11. (a) $\varepsilon N d$ versus $\mathrm{Th} / \mathrm{Sc}$ ratio for mélange and the mudstones and sandstones of the Viqueque and Marobo Basins, and for modern seafloor sediments. Babulu and Aileu fields from data of Boger et al. (2016). (b) Latitudinal trend of Vroon et al.'s (1995) data to most negative $\varepsilon N d$ on the north side of the orogenic wedge, where sediment is largely derived from erosion of the Gondwanan lithologies exposed on the north side of the drainage divide in Timor.

top left of the plot (McLennan et al., 1993). The Viqueque section mudstones and sandstones had less negative $\varepsilon N d$ values and lower $\mathrm{Th} / \mathrm{Sc}$ ratios than the Marobo rocks; this is consistent with a less evolved bulk provenance for the Viqueque mudstones, compared with a more evolved provenance for the Marobo section.

All samples had bulk provenance depleted mantle model ages $\left(\mathrm{T}_{\mathrm{DM}}\right)$ in excess of $1.6 \mathrm{Ga}$, and $\varepsilon N d$ values of -9.8 to $-14(-15.6$ for mélange). The Proterozoic Nd model ages and $\varepsilon N d$ values of the synorogenic mudstones of Timor are not compatible with the age, tectonic setting or $\varepsilon N d$ values of the Banda Terrane and related rocks (Harris, 2006; Honthaas et al., 1998; Morris et al., 1984; Standley and Harris, 2009; Vroon et al., 1993) (Fig. 11). Gondwanan Maubisse Formation samples on Timor yield negative $\varepsilon N d$ values (Fig. 11); however, the Gondwanan volcanics are Permian in age, substantially younger than the Proterozoic bulk provenance model age calculated for the mudstones of the Viqueque Formation (Table S7).

The synorogenic model ages may be affected by a combination of carbonate contamination and post-depositional fractionation of Sm by authigenic apatite (e.g., Ehrenberg and Nadeau, 2002). Nevertheless, the synorogenic mudstones have similar model ages and $\mathrm{Th} / \mathrm{Sc}$ ratios to modern sediments accumulating in the Timor region (Vroon et al., 1995). Vroon et al.'s (1995) seafloor sediment data shows a latitudinal trend across the arc (Fig. 11b), with the most negative $\varepsilon N d$ and oldest model ages found on the orogenic wedge north of Timor. The Marobo samples plot close to these values (Fig. 11a). The northern half of Timor is presently dominated by outcrop of the shales (particularly Babulu Formation and Synorogenic Mélange), sandstones and metamorphic rocks of the Gondwana Megasequence (Fig. 1). The Viqueque mudstones plot in the less-evolved field occupied by seafloor sediments presently accumulating on the southern part of the orogenic wedge, where most of the Banda Terrane sediments are shed.

The modern sediments and Viqueque mudstones plot generally on a mixing line between Synorogenic Mélange and Banda metabasites, with mudstone plotting closer to the mélange in both the Marobo and Viqueque basins. The Synorogenic Mélange has a similar model age, Th/Sc ratio and $\varepsilon N d$ value to Australian shales (Allègre and Rousseau, 1984) (Fig. 11), which is consistent with an Australian affinity. The present data is not suitable to differentiate between a mélange sourced from abyssal shales at the base of the Australian Margin Megasequence in the Kolbano region (e.g.,
Charlton, 1989; Sawyer et al., 1993), which would have provided the bulk of sediments incorporated in the Timor accretionary wedge, or from remobilized Triassic Australian shales. However, our mélange sample has more negative $\varepsilon N d$ than the limited data from either Babulu or Aileu Triassic shales (Boger et al., 2016).

\subsubsection{Clast chemistry}

Petrography of the conglomerates indicates that the Viqueque and Laleia Basins contained a large proportion of amphibolite and basaltic clasts. We compared their chemistry with similar lithologies reported from both the Gondwana Megasequence and Banda forearc Terranes (Berry and Jenner, 1982; Park et al., 2014; Standley and Harris, 2009) (Fig. 12). The clasts lie in a zone of overlap between Gondwanan and Banda basaltic rocks on Roser and Korsch and Winchester and Floyd discrimination diagrams (Fig. $12 \mathrm{a} \& \mathrm{~b}$ ). However, the REE and trace element chemistry of the clasts (Fig. $12 \mathrm{c} \& \mathrm{~d}$ ) is more consistent with the N-MORB affinity, slightly Eu-depleted rocks of the Banda Terrane (Park et al., 2014) rather than the ocean island basalt, slightly positive Eu anomaly characteristics of the Gondwanan basalts (Berry and Jenner, 1982). A dolerite block in the Synorogenic Mélange near Bobonaro also yields typical Banda geochemistry. Non-basaltic clasts from all sections exhibited typical calc-alkaline REE profiles with LREE enrichment and moderate negative Europium anomalies (Fig. 12e\&f). These characteristics are consistent with a Banda Terrane source for the clasts.

\subsubsection{Chemical constraints on source area weathering}

Weathering of rocks results in enrichment of $\mathrm{Al}_{2} \mathrm{O}_{3}$ at the expense of alkalis. The effect, along with the effects of diagenetic $\mathrm{K}$ metasomatism, can be evaluated using the Chemical Index of Alteration (CIA, Fedo et al., 1995; Nesbitt and Young, 1982) (Fig. 13A). The CIA was calculated from molar proportions of oxides in mudstone samples using the formula

$\mathrm{CIA}=\mathrm{Al}_{2} \mathrm{O}_{3} /\left(\mathrm{Al}_{2} \mathrm{O}_{3}+\mathrm{CaO}^{*}+\mathrm{Na}_{2} \mathrm{O}+\mathrm{K}_{2} \mathrm{O}\right) \times 100$

where $\mathrm{CaO}^{*}$ is silicate $\mathrm{CaO}$. Dolomite was not detected by XRD so the molar proportions of major elements were used to calculate $\mathrm{CaO}^{*}$ using the formula

$\mathrm{mol} \mathrm{CaO}^{*}=\mathrm{mol} \mathrm{CaO}-\mathrm{mol} \mathrm{CO} 2-10 / 3 \mathrm{~mol} \mathrm{P}_{2} \mathrm{O}_{5}$

This calculation corrects for carbonate content (through $\mathrm{CO}_{2}$ ) and apatite (through $\mathrm{P}_{2} \mathrm{O}_{5}$ ) and thus removes the influence of non-silicate $\mathrm{CaO}$. CIA is meaningless (hence not calculated) for carbonate rocks, so phosphate enrichment is not problematic.

The mudstone sediments of both basins plot along a trend approximately parallel to the $0 \% \mathrm{~K}_{2} \mathrm{O}$ line, and show little evidence of diagenetic $\mathrm{K}_{2} \mathrm{O}$ addition (Fig. 13A) (e.g., Fedo et al., 1995). The low $\mathrm{Al}_{2} \mathrm{O}_{3}$ values indicate that the weathering in the source area was only moderate and average CIA value did not vary between sections. The average CIA value of the Viqueque section is $67.8 \pm 7$ and of the Marobo section was $67.7 \pm 2.6$. No temporal trends are observed (Fig. 13B). Individual conglomerate clasts have lower CIA values in general than the mudstones. Their CIA values are close to the primary CIA values of unweathered rocks, suggesting that they are only minimally weathered.

Th concentrations and Th/U ratios are lowest in depleted mantle and increase during weathering and sedimentary recycling as the $\mathrm{U}$ is mobilized. Fig. $13 \mathrm{C}$ is a plot of Th/U vs. Th (McLennan et al., 1993). The Th/U ratios of the Batu Putih rocks in both the Marobo and Type sections lie within the range of depleted mantle sources typical of volcanic arc rocks (Fig. 13C). However, the local volcanic arc rocks from Wetar and Atauro are Th-enriched by comparison with the terrigenous source for the Batu Putih marls. The Th/U ratio of the Batu Putih Formation rocks remains generally 

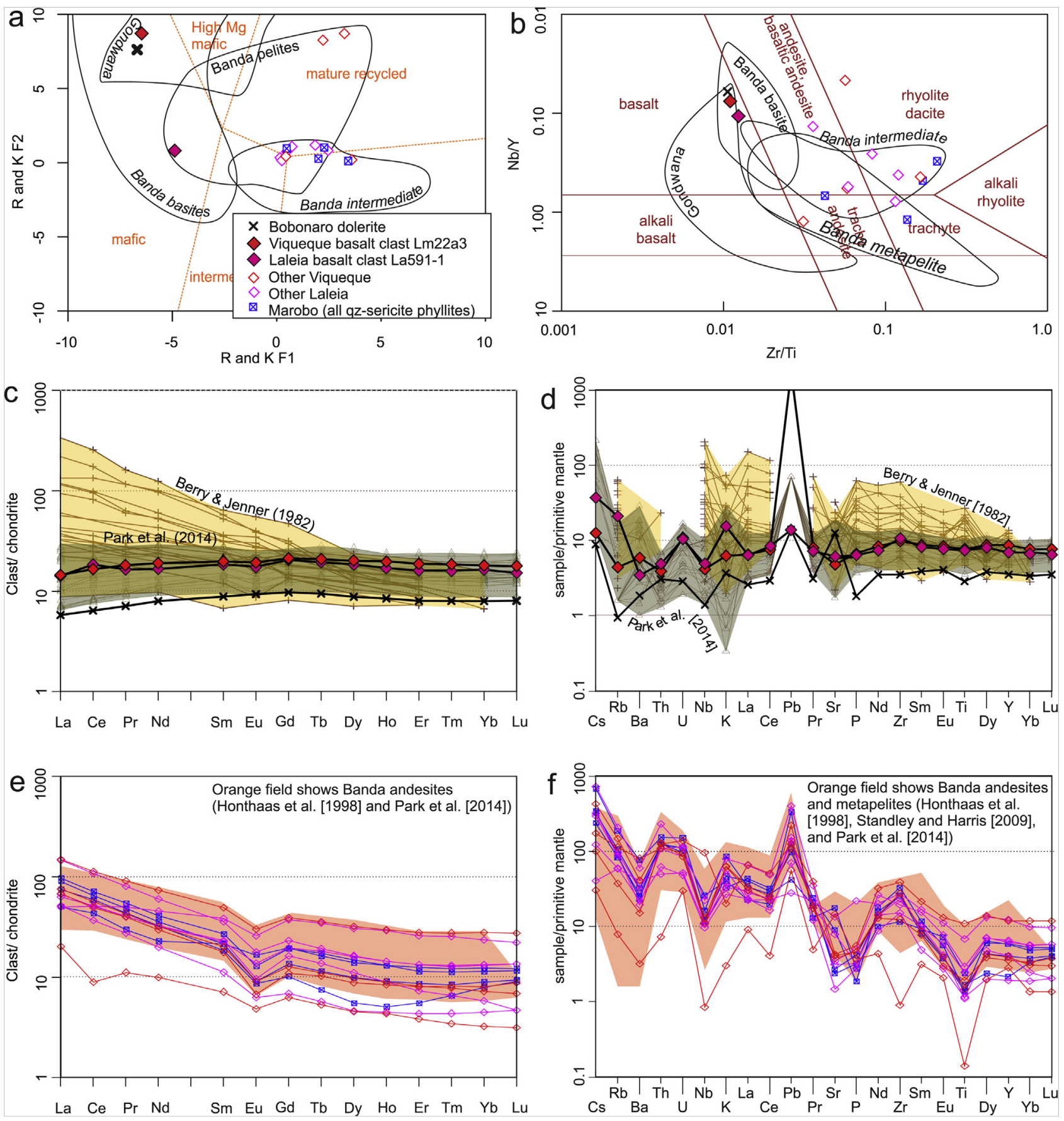

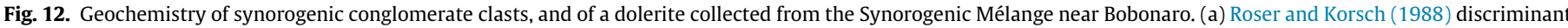

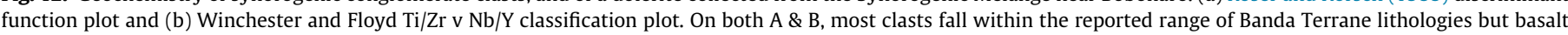

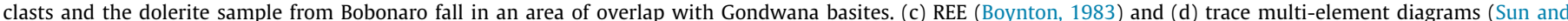

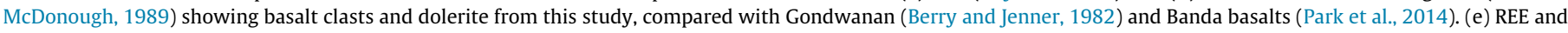
(f) trace multi-element diagrams comparing other sedimentary and metapelitic clasts from synorogenic rocks with available data for Banda andesites and metapelites.

stable as Th concentrations increase (Fig. 13D), with the exception of several of the youngest samples (bold in Fig. 13A), mostly from the Viqueque section. These particular samples are enriched in $U$ relative to the carbonate dilution trend (Fig. 6b), probably due to biogenic uranium similar to sea floor sediments sampled across the Timor orogenic wedge and in DSDP 262 (Vroon et al., 1995). The Th/U ratios of the mudstone sections show a poorly-defined trend of increased weathering upwards through the section that is clearer in the Marobo mudstones (Fig. 13B). Together, the CIA and $\mathrm{Th} / \mathrm{U}$ data indicate only moderate weathering intensity, with a minor increase in weathering upsection (Fig. 13D).

\section{Discussion}

\subsection{Transition from carbonate to terrigenous sedimentation - an uplift record}

In all the studied basins across Timor, the base of dated sections occupies a narrow range of $60 \mathrm{kyr}$ between 5.59 and $5.53 \mathrm{Ma}$, has a deep marine foraminiferal assemblage and overlies the Synorogenic Mélange (Haig and McCartain, 2007; Tate, 2014; Tate et al., 2014). Even though the 5.5-4.5 Ma basal sediments of the Marobo and Viqueque sections of Timor-Leste must have accumulated 

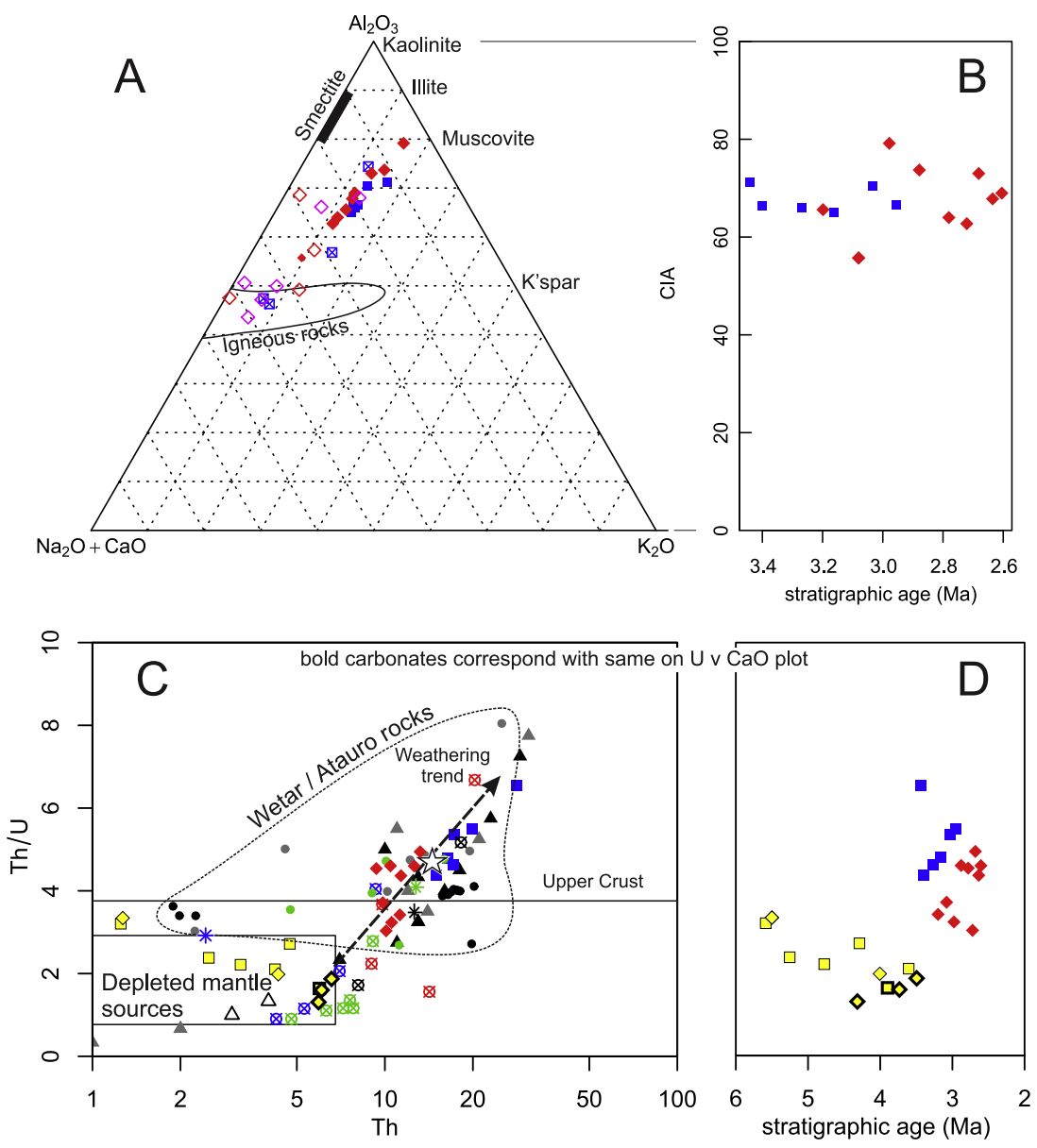

Synorogenic

Vqq type section carbonate

- Vqq type section mudstone

Marobo section carbonate

- Marobo section mudstone

Marobo section sandstone

$\boxplus$ DSDP 262 (Cook, 1974)

DSDP 262 (Vroon et al. 1995)

sed. arc (Vroon et al. 1995)

sed. wedge (Vroon et al. 1995)

sed. shelf (Vroon et al. 1995)
Gondwana

+ basalts

Banda Terrane

$\triangle$ LM metabasites

* Average LM metabasite

- LM metapelites

* Average LM metapelite

- LM altered/ultramafic

Volcanic Arc

- Atauro (Ely et al. 2011)

- Wetar (Elburg et al. 2005)

- Wetar (Herr'ton et al. 2011)

* Average Arc volcanics

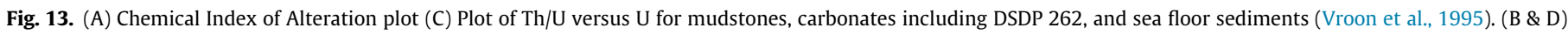
Temporal variations in $\mathrm{CIA}$ and $\mathrm{Th} / \mathrm{U}$.

within $200 \mathrm{~km}$ from the arc, which was active between at least 7.1 Ma (Abbott and Chamalaun, 1981; Honthaas et al., 1998) and 2.4 Ma (Ely et al., 2011; Herrington et al., 2011), the sediments have high carbonate content, very low levels of terrigenous minerals and elements, and low organic carbon content. Apart from the underlying mélange, the first indication of tectonic activity affecting the synorogenic sections is the influx of terrigenous sediment into the pelagic carbonate Batu Putih Formation, which gives rise to marl rather than carbonate sedimentation by $4.5 \mathrm{Ma}$. This event begins synchronously at the Viqueque and Marobo sections, within the resolution of the data (Fig. 7), and increases from close to the base of the section. Similar age transitions to marl are also documented in Savu, West of Timor (Roosmawati and Harris, 2009). Our trace element data supports Nguyen et al.'s (2013) conclusion (based on major elements) that any contribution from a rhyo- dacitic source area, such as the arc north of Timor is minor; even the oldest sediment has $\mathrm{Y} / \mathrm{Ni}$ ratios that are well outside the range of arc rocks from Atauro and Wetar (Fig. 9). The felsic initial trace element ratios of the basal carbonates indicate that their high $\mathrm{Mg}$ concentrations (Fig. 8) represent incipient diagenetic dolomitization of the older rocks (less developed than at DSDP262), rather than an ultramafic (i.e., Banda Terrane) source input.

The purity of the basal Timor-Leste carbonates suggests that mud did not disperse widely in the region of Pliocene Timor, which virtually precludes other Indonesian sources for the lithogenic mud and demands a local source. Timor's austral summer monsoon presently coincides with the weakest flows of the Indonesian Throughflow (ITF) (Cecil et al., 2003), which limits modern long-range dispersal of mud. The extent to which this limits other exotic sources is shown by the development of an Eastern Indonesian clay 
province around Timor (north of the trough) that has high chlorite and kaolinite (Gingele et al., 2001) compared with smectite rich clays south of the trough. The evidence for poor mud dispersal indicates that the change from clean pelagic carbonates to marls at the Marobo and Viqueque sections records the emergence of a nearby proximal landmass prior to $4.5 \mathrm{Ma}$, rather than mud influx from a distal source (Haig, 2012; Nguyen et al., 2013; Tate et al., 2014).

The Sm/Nd and major, trace and REE geochemistry of the Batu Putih Formation and the Viqueque Formation mudstones, together with the negative $\varepsilon N d$ and old Nd model ages of Viqueque Formation mudstones, show that Australian shales of the Synorogenic Mélange or its precursors have provided a local and substantial source of mud that began with the marly sediment and continues to dominate the modern fine-grained sediments accumulating on the orogenic wedge (Vroon et al., 1995). The chemistry of the Banda Terrane components in the synorogenic muds provides little more than an overprint to the mélange geochemistry.

The overwhelming and persistent influence of mélange-like elements on synorogenic geochemistry attests to the volume of lower-plate material that is reworked into the synorogenic basins from a very early stage. This wholesale reworking of strata from the base to the top of the orogen needs to be carefully accounted for in estimates of shortening and thickening (e.g., Tate et al., 2015). This is especially important in [fore] arc-continent collisions, where mélange-forming processes are almost ubiquitous (Barber et al., 1986; Chang et al., 2001; Duerto and McClay, 2011; Festa et al., 2010; Hall and Wilson, 2000; Harris et al., 1998; Rangin et al., 1990; Williams et al., 1984; Yu and Jiunn Chenn, 1995) and may occur throughout pre-collisional to collisional stages (Barber, 2013). Moreover, this study also illustrates the potential for the recycled products of shale tectonics to control the $\mathrm{Sm} / \mathrm{Nd}$ provenance signature in mudstones derived from arc-continent collision zones. If studied basins in other orogens are distal, shale-dominated, and tectonically isolated from the source area, reconstruction of their tectonic setting may be problematic. For instance, Miller and O'Nions (1984) found that shales, slates and clay sediments in Britain did not tend to record the accretion of young mantle derived material during the Caledonian, Hercynian and Grenville orogenies. Results such as this may reflect the importance of remobilization and reworking of continental shales during arc-continent collision.

\subsection{Clastic provenance}

\subsubsection{Laleia and Viqueque basins}

The Viqueque Basin is part of the E-W elongate Southern Basin, and the Laleia Basin is part of the NE Basin (Fig. 1). The basins have differing clast provenance. The Laleia Basin contains lithologies such as volcaniclastic limestones and dacites that indicate a source similar to the Banda Terrane Palelo Group, a forearc cover sequence that overlies the forearc basement of the Lolotoi Metamorphic Complex (Fig. 2) (Harris, 2006). Dacites are common in the Banda Terrane; they are reported to overlie the Banda Terrane Mosu massif of West Timor (Standley and Harris, 2009) and are also found as Paleocene to Miocene intrusive and extrusive rocks in the forearc basement of Sumba (Chamalaun et al., 1982; Rutherford et al., 2001; Wensink, 1994), where they are associated with metasomatized basalts and are commonly slightly altered to secondary assemblages that include chlorite, albite and carbonate (Wensink and van Bergen, 1995). These same associations and mineral assemblages are characteristic of the dacite clasts in the Laleia conglomerates and suggest that the Laleia Basin fill was derived from erosion of Banda Terrane cover rocks of the Palelo Group.

In contrast, the conglomerate clasts of the Viqueque Basin have crystalline lithologies that are consistent with a dominantly metamorphic source similar to the Banda Terrane Lolotoi metamorphic complex that lies below the Palelo Group. Epidote amphibolite schist is reported from the Lolotoi-equivalent massifs of West Timor (Earle, 1981; van West, 1941), along with amphibolites, metagabbros and peridotite (Earle, 1981; Sopaheluwakan et al., 1989). Both the Banda Terrane and the Gondwana Megasequence contain basalts and amphibolites (Audley-Charles, 1968; Berry and Jenner, 1982; de Roever, 1940, 1942; Standley and Harris, 2009). However, the mylonitized amphibolites, particularly in association with granophyric rocks, seems consistent with metamorphic rocks of the Atapupu area of West Timor (Helmers et al., 1989; Ishikawa et al., 2007). Furthermore, the albite deformation seen in the Viqueque conglomerate clasts suggests high temperature metamorphism, which is overprinted by stretching, mylonitzation and retrogression, leading to the growth of tremolitic amphibole into the feldspars and amphiboles. This history is consistent with the tectonic history of the Banda Terrane (Harris, 2006; Standley and Harris, 2009). Small percentages of the clasts in both basins, particularly silicified limestones, point to a source in the Gondwanan Maubisse Formation (e.g., Barkham, 1993). However, these lithologies are common in the Synorogenic Mélange, which was the dominant source for mudstone and therefore widespread in the source area.

The present lack of age constraints on the Laleia Basin precludes a rigorous assessment of the reasons for the differences between the basin source lithologies; however, the two basins presently lie either side of a dextral-normal fault, indicating that the Laleia Basin originally lay further west relative to the Viqueque Basin (Duffy et al., 2013).

\subsubsection{Marobo basin}

The Marobo Basin is a narrow graben that subsided relative to, within, and perpendicular to the proto-Timor mountain belt (Duffy et al., 2013). The down-throw of the basin, and its concurrent uplift from bathyal depths, occurred at times and rates that are indistinguishable from the uplift history of the Viqueque section (Tate et al., 2014), and were interpreted to result from differential duplexing (Duffy et al., 2013; Tate et al., 2014). Despite the similar timing of events, the rocks of the Marobo Basin have a provenance that is both petrographically and geochemically distinct from that of the more eastern Laleia and Viqueque Basins. Apart from four weathered volcanic clasts in sample CR24A from the base of the clastic succession (Table S6), the source area for the Marobo Basin was one of highly strained metapelites that are more geochemically evolved compared with the underlying Batu Putih Formation and the Viqueque mudstones (Fig. 9). This is reflected in the higher concentrations of REE and HFSE in the mudstones (Fig. 10), and in their high Th/Sc ratios compared with the Viqueque Basin (Fig. 11). The sericite schist-dominated lithology and the chemistry of the Marobo clasts (Fig. 12) is completely consistent with the characteristics of metapelites from the Banda Terrane in West Timor (de Roever, 1940; Earle, 1981; Standley and Harris, 2009), TimorLeste (Audley-Charles, 1968; Park et al., 2014; Standley and Harris, 2009) and continental fragments embedded in the seafloor of the Banda Sea (Honthaas et al., 1998).

\subsection{Location of clastic source area}

The character and timing of sedimentation at DSDP 262 may provide clues to the distance separating the Viqueque Basin and the emergent, Banda dominated landmass. DSDP 262, which is located at the modern deformation front at $2298 \mathrm{~m}$ (more or less similar to the paleodepth of the basal clean carbonates in the exhumed sections), was still accumulating clean carbonates while the Marobo and Viqueque Basins were accumulating coarse clastic sediment (Fig. 7), but began a similar trend of increasing terrigenous sedimentation about $2.8 \mathrm{Myr}$ later. This late onset of 
increased terrigenous sedimentation rates and overall increased sedimentation rates (Fig. 5b) immediately postdates the projected emergence of the Central Basin based on Tate's (2014) reevaluation of the biostratigraphy of the key Sabau section in West Timor. It also coincides approximately with the timing of emergence of Roti and Savu (Roosmawati and Harris, 2009), although these islands are downstream from DSDP 262 in the Indonesian Throughflow so this is probably not significant. Overall, it seems likely that the change in sedimentation at DSDP 262 occurred when the subaerial West Timor landmass widened and expanded during the course of sustained and constant uplift. This expansion would have reduced the distance between DSDP 262 and the Timor landmass to $\sim 50 \mathrm{~km}$. Following this logic, the Viqueque section probably lay roughly $50 \mathrm{~km}$ southeast across strike from the shoreline at 3.1 Ma. Balanced cross-sections imply that the distance between the high grade rocks and the site of the synorogenic sedimentation in south coast basins has been $\sim 55-60 \mathrm{~km}$ since the onset of deposition of Batu Putih rocks (Tate et al., 2015). This puts the source within the present landmass, which is consistent with published thermochronology (Tate et al., 2014) and may aid in understanding the source area.

The high-grade belt on the north coast of Timor presently lies some $55-65 \mathrm{~km}$ across strike from the Viqueque Basin. It appears to have already been exhumed some $6-10 \mathrm{~km}$ by the time sandstones began accumulating at Viqueque (Tate et al., 2014), possibly as a result of slumping on the northern margin of an antiformal stack (Tate et al., 2015). However, no high-grade rocks attributable to this repeatedly documented exhumation episode (Berry and McDougall, 1986; Ely et al., 2014; Tate et al., 2014) are found in the synorogenic sediments; along with the large time lag between exhumation and clastic sedimentation, this lends support to models of submarine tectonic denudation (Harris, 2011; Tate et al., 2015) as a driver for the early exhumation.

The Viqueque Basin is located in the foreland region, where Tate et al.'s (2014) apatite U-Th/He data show there had been only a few hundred meters of exhumation by the onset of clastic sedimentation. That few hundred meters probably represents recycling of uplifted synorogenic sediments, and is represented in the provenance by the intraclasts that occur at all scales within the sandstones. It is insufficient to account for the rounded detritus in the Viqueque Basin.

The remaining source area that shows reasonable exhumation to account for the intraclasts and the rounded Banda detritus is the present Aileu region, parts of which Tate et al. (2014) show must have been exhumed by some $2.5 \mathrm{~km}$ at that time. Their estimated exhumation rates suggest that these rocks probably exhumed a further $500 \mathrm{~m}$ during deposition of the $250 \mathrm{~m}$ thick Viqueque section. A Banda Terrane source overlying the present Aileu is supported by paleoflow indicators in the Marobo Basin: after removing the $\sim 65^{\circ}$ anticlockwise vertical axis rotation of the basin (Aben et al., 2014), the southerly paleoflow of the clastic sediments represents deposition from the central western Aileu region to the east of the basin.

We suggest here that the early Pliocene exhumation of the Aileu region must have involved erosion of Australian affinity, mélangelike shales, which form the lithogenic component of the marls. Useful context for this interpretation is provided by the Cota Taci-1 exploration well at Suai (Fig. 7 in Charlton, 2002a). The well is located a few kilometres west of Tate et al.'s (2015) balanced section but was not part of their cross section constraints. The well terminated in Banda Terrane basement after passing through Viqueque Formation, at least $1 \mathrm{~km}$ of mélange and the Dartollu Limestone of the Banda Terrane cover sequence, providing strong evidence for the presence of a thick mélange overlying the Banda Terrane. Within the mélange the well encountered several blocks of Banda metamorphic rocks and cover sediment.
The concept of multiple mélanges with the same source rocks, but at different structural levels within, in front of, below and atop a Banda Terrane nappe is consistent with observations from the Banda Arc (Barber, 2013; Barber et al., 1986; Harris et al., 1998) and from numerous mélange occurrences globally (Festa et al., 2010); epi-nappe melanges usually have a sedimentary or diapiric/mud volcanic origin. In Timor-Leste, siliceous argillites of the Noni Formation (a Banda Terrane cover unit - Fig. 2) are found in the Synorogenic Mélange of the Viqueque area (Haig and Bandini, 2013), and are particularly unlikely to be found at the base of the Banda nappe (c.f., Tate et al., 2014); this implies that the $2 \mathrm{~km}$ of mélange that underlies the basin (based on the Ossulari1 well south of Viqueque - Audley-Charles, 1968) overlies Banda Terrane rocks. Our interpretation further implies that Banda Terrane rocks overlay the Aileu rocks in the Pliocene. This interpretation, along with previously published metamorphic ages (Harris, 2006), is inconsistent with a model in which the Lolotoi Metamorphics are interpreted as Australian basement (e.g., Charlton, 2002a).

\subsection{Analogues for provenance area and implications for topographic evolution}

The islands of Savu and Rote are exhumed elements of the outer-arc Savu-Rote accretionary ridge (Harris et al., 2009; Rigg and Hall, 2012; Roosmawati and Harris, 2009). They are located west of Timor and provide an opportunity to gain insight into the interplay between geology and uplift in a similar setting to proto-Timor. Rote Island $\left(1273 \mathrm{~km}^{2}\right.$, max elev $\left.445 \mathrm{~m}\right)$ is the youngest island to emerge in the outer Banda Arc at $\sim 0.3 \mathrm{Ma}$ (Roosmawati and Harris, 2009). Wai Luli Formation Gondwanan mudstones are exposed at the surface across much of the island, and rock fragments of similar composition to several Banda Terrane units are found in mud diapirs near the north coast, suggesting that the Banda Terrane underlies the island within $50 \mathrm{~km}$ of the trench (Roosmawati and Harris, 2009). At present, the island shows indistinguishable pre-emergence (Roosmawati and Harris, 2009) and post-emergence uplift rates of $\sim 1.5 \mathrm{~mm} / \mathrm{yr}$ (Merritts et al., 1998). However, the outcropping Gondwanan mudstones are very erodible and only $15 \%$ of Rote exceeds $160 \mathrm{~m}$ elevation, all of which is capped by reefs. These reefs are unconformable on Batu Putih Formation, because they overlie the first part of the accretionary prism to emerge and thus predate Viqueque-equivalent clastic sedimentation.

Savu Island (area $\sim 420 \mathrm{~km}^{2}$, max elev $\sim 338 \mathrm{~m}$ ) is similarly dominated by outcrop of erodible, Gondwanan, Wai Luli and Babulu Formation mudstones. The Savu \#1 well drilled on the north coast penetrated at least $800 \mathrm{~m}$ of mélange and $300 \mathrm{~m}$ of Batu Putih Formation overlying the Banda Terrane, which was encountered at a depth of $1227 \mathrm{~m}$ (Harris et al., 2009). As we see at Viqueque, blocks encountered in the mélange include many units reported from the Banda Terrane. Savu, like Rote, still has synemergence reefs encrusting high (although not highest) elevations, but again only $15 \%$ of its surface exceeds $160 \mathrm{~m}$ elevation. Savu's post-emergence surface uplift rate is less than half the preemergence submarine surface uplift rate (Harris et al., 2009; Roosmawati and Harris, 2009), possibly as a result of changes in activity on the Savu Thrust system. Rivers on Savu display profiles that are generally concave up but with minor upward convexity in some lower reaches (Harris et al., 2009).

The generally low and strikingly similar elevations of both Rote and Savu, despite their different emergence ages, land areas and uplift rates, and the generally concave up river profiles on Savu, suggest that these islands are approximately in dynamic equilibrium between erosion and uplift, and that the erodible cover on the Banda Terrane will be removed efficiently over the next 1- 
2 million years without significant further elevation gains. This contrasts markedly with the island of Sumba, which is a Late Cretaceous and Cenozoic arc and forearc basin (Effendi and Apandi, 1981) that emerged since $3 \mathrm{Ma}$ (Fortuin et al., 1997). A wellpreserved flight of coral terraces in the central north coast of Sumba yields a constant uplift rate of $0.5 \mathrm{~mm} / \mathrm{yr}$ for $\sim 1 \mathrm{Myr}$ (Pirazzoli et al., 1993), which is intermediate between Savu and Rote and broadly consistent with pre-emergence uplift rates derived from foraminiferal paleobathymetry (Fortuin et al., 1997). Sumba has an area of $11,200 \mathrm{~km}^{2}$ and a maximum elevation of $1209 \mathrm{~m} .15 \%$ of the island exceeds $540 \mathrm{~m}$ elevation, compared with the $160 \mathrm{~m}$ equivalent value for Savu and Rote. The landscape is far from dynamic equilibrium, and most of Sumba's river channels are in a transient state due to both active uplift and relatively strong lithologies that impart a staircase morphology to the rivers (Nexer et al., 2015).

The comparative geology and geomorphology of Savu/Rote and Sumba demonstrates a coupling between erodibility and surface uplift that may partly explain the coincidence of accelerated uplift and Banda-derived sedimentation (Nguyen et al., 2013). The hinterland of proto-Timor was exhuming at an average of $1-3 \mathrm{~mm} /$ yr during deposition of the Batu Putih and Viqueque Formations (Tate et al., 2014). Surface uplift rates during Batu Putih deposition were around $0.2 \mathrm{~mm} / \mathrm{yr}$ [Nguyen et al. (2013), revised here based on the Aben et al. (2014) age model (Fig. 7)] and uplifted protoTimor to only around $\sim 220 \mathrm{~m}$ elevation (Fig. 7c). This implies that 83-93\% of rock uplift (equal to surface uplift + exhumation) was removed by $\sim 1.2-3.2 \mathrm{~mm} / \mathrm{yr}$ of erosion, i.e., a situation of dynamic equilibrium, comparable to Savu and Rote. This would have been approximately enough to remove the thickness of mélange seen in the Ossulari-1 and Cota Taci- 1 wells, and in Rote and Savu, thus exhuming but not greatly eroding the underlying the Banda Terrane.

There ensued a period of uplift at $\sim 8 \mathrm{~mm} / \mathrm{yr}$ [our revision of Nguyen et al.'s (2013) uplift rate (Fig. 7c)] that began synchronously with the onset of Banda-derived turbidite sedimentation. This would have required a major increase in rock uplift rates, of at least $4.5-6.5 \mathrm{~mm} / \mathrm{yr}$, which may have been driven by either backthrusting on the Wetar Suture (Price and AudleyCharles, 1987), or duplexing between the basin and the source. However, the requirement for increased rock uplift was probably offset by $\sim 1-3 \mathrm{~mm} / \mathrm{yr}$ by reduced erosional efficiency as low topography, diffusive, denudational processes failed to keep pace with uplift of a wide zone of newly-emergent, resistant forearc basement. Eventually, the pulse of rapid uplift would have slowed as a rainshadow developed (Nguyen et al., 2013), and as gravitational instabilities such as deep-seated landsliding arose in a oversteepened, rapidly incising, landscape. These factors would have served to accelerate the erosion of the Banda Terrane and restore the dynamic equilibrium between rock uplift and erosion, creating a landscape like much of Timor-Leste today.

The origin of the thick sheet of Australian mélange-like shales in Timor is unclear but as shown in Fig. 2, and as seen in Savu (e.g., Fig. 2 in Harris et al., 2009) it probably represents a combination of (1) material intruded through the Banda Terrane from overpressured shales below, and (2) Australian units thrust over the leading edge of the Banda Terrane, either as an accretionary prism or as a decollement propagated through the Triassic rocks. In any case, there is likely to be a diapiric component to the deformation of the overpressured shales (e.g., Barber, 2013).

The source-to-basin distance of the north coast area of Timor, and its timing of exhumation, together with the factors discussed above, make it a prime candidate for the source of the synorogenic sediments. The Viqueque Basin presently lies on the opposite side of the main divide to the north coast sediment source, so the divide must have migrated since deposition of the Viqueque Basin sedi- ments. Divide migration is predicted by numerical models of mountain belt geomorphology, which suggest that the topographic divide is offset toward the retrowedge side of the landmass (Willett et al., 2001). Early in the collision, Timor would have grown by frontal accretion on the south side of the island and the divide would have been located close to the north (retrowedge) coast of Timor. The reduction in contraction in the vicinity of the Timor Trough, from $70 \mathrm{~mm} / \mathrm{yr}$ to $20 \mathrm{~mm} / \mathrm{yr}$ (Koulali et al., 2016; Nugroho et al., 2009) and the progressive change to north vergent thrusting, would be expected to reduce the asymmetry and move the divide southward.

\subsection{Chemical weathering}

The new tropical landmass of proto-Timor might be expected to have been a focus for chemical weathering. However, the CIA and Th/U data indicate only moderate weathering intensity, with a minor increase in weathering upsection (Fig. 13D). This suggests that erosion was keeping pace with chemical weathering and fresh rock was being quickly exhumed at the surface. Timor's climate limits chemical weathering due to the long dry season, which stresses vegetation and maximizes the erosive power of the monsoons (e.g., Harris et al., 2008). Erosional denudation of Timor then is primarily driven by tectonic activity (e.g., Quigley et al., 2007). The low intensity of weathering throughout the deposition of the Viqueque Formation (Fig. 13) is consistent with the rapid tectonic uplift. The slightly higher degree of weathering in the source area for the Viqueque section is probably related to its more mafic and variable composition as seen in the petrography and geochemistry.

\subsection{Timing and rates of deformation in the western Timor Trough}

Veevers et al. (1978) proposed a depth-facies history for the DSDP 262 site, and related it to the encroachment of the Timor fold and thrust belt. Comparison of their interpretations with the improved age model suggests that, south of West Timor, the Timor Trough advanced southward toward the shelf at $\sim 35-40 \mathrm{~km} / \mathrm{Myr}$ between 4 and $2 \mathrm{Ma}$ and the migration rate reduced to $5-10 \mathrm{~km} /$ Myr at $\sim 2 \mathrm{Ma}$. These data record rates of transport of the DSDP site as fixed on the Australian Plate, toward the deformation front, which is a proxy for shortening, but can be increased by a reduction (or reduced by an increase) in the critical taper of the wedge. Tate et al. (2015) suggested that total shortening of the eastern part of the orogen between 4.5 and 2.0 Ma occurred at a (slower than W. Timor) rate of $\sim 22 \mathrm{~km} / \mathrm{Myr}$, and increased to a (faster than W. Timor) rate $35 \mathrm{~km} / \mathrm{Myr}$ between $2.0 \mathrm{Ma}$ and the present time. The DSDP 262-based estimates amount to $83 \mathrm{~km}$ over $4 \mathrm{Myr}$, or $\sim 21 \mathrm{~km} / \mathrm{Myr}$, but records only the foreland component of shortening. Tate et al.'s (2015) estimates of total shortening for TimorLeste amount to $\sim 28 \mathrm{~km} / \mathrm{Myr}$ over the same period of time. Given that the Timor-Leste shortening estimates include substantial northward thrusting over the forearc, and the DSDP-based estimates record only the foreland component, the difference in timing of shortening and general agreement of overall shortening suggest that: (a) there is little difference in the timing of events in TimorLeste and West Timor; (b) most of the shortening in West Timor must be accomodated in the foreland, and (c) the critical taper in West Timor is behaving independently of the taper of the eastern orogeny. Also, some of the convergence in West Timor since 2 Ma may have been accommodated by thrusting over the forearc.

\section{Conclusions}

We have presented new data for the Synorogenic Megasequence from several basins including well-dated measured sec- 
tions in central and eastern Timor (the Marobo and Viqueque basins respectively) and a re-dated DSDP 262. Our analysis indicates that:

(1) Arc magmatism did not contribute to the sediments accumulating on the forearc since $>5.5 \mathrm{Ma}$.

(2) The geochemical evolution of DSDP 262 sediments records the emergence of modern land at a distance of $\sim 50 \mathrm{~km}$.

(3) In the exhumed synorogenic basins, the DSDP 262equivalent Batu Putih Formation becomes progressively more marly upwards due to an influx of terrigenous sediment derived from erosion of the Synorogenic Mélange, which began prior to $4.5 \mathrm{Ma}$.

(4) Comparison of the provenance evolution with published sections and thermochronology suggests that the muddy sediments were sourced from rocks above the area currently exposing the Aileu Complex, $\sim 50 \mathrm{~km}$ from the basins.

(5) Erosion of the mélange-like rocks overlying the Banda Terrane exhumed the Banda Terrane to the surface in the region where Aileu metamorphic rocks are presently exposed.

(6) The differential erodibility of the mélange and Banda Terrane contributed to rapid surface uplift of the hinterland and shed Banda-derived detritus into the sedimentary basins.

(7) Revision of existing facies interpretations of DSDP 262 on the basis of improved age constraints supports a model of relatively synchronous collision across the island of Timor.

Overall, this study highlights the important influence of mélange processes and their impact on differential erosion for the geodynamic development and the sedimentary record of young collisional belts. Importantly, the recycled products of shale tectonics may dominate the $\mathrm{Sm} / \mathrm{Nd}$ provenance signature in mudstones derived from arc-continent collision zones, leading to problematic reconstructions of basin setting in shale sequences.

\section{Acknowledgements}

This research was primarily funded by a Royal Society of New Zealand Marsden Fund grant to MQ (Fast-start grant M1137). BD was supported by a New Zealand Tertiary Education Commission Top Achiever Scholarship. RH was supported by various NSF grants. DJJvH was supported by ERC - Netherlands Starting Grant 306810 (SINK) and NWO VIDI - Netherlands grant 864.11.004. The authors gratefully acknowledge the support of the University of Canterbury, where much of this research was conducted, and of our Timorese colleagues Jhony Suares, Lamberto Fernandes, Jhony dos Reis, Lourenco Pedro, and Andy Monteiro for support and camaraderie during our field campaigns. We are indebted to the Institute for Petroleum and Geology in Timor-Leste for their work to facilitate our research. Publication costs are covered by a UoM startup grant for $\mathrm{BD}$. The authors gratefully acknowledge the efforts of Drs. Anthony Barber and Timothy Charlton, whose review comments were of great help in crafting the final version of this manuscript.

\section{Appendix A. Supplementary material}

Supplementary data associated with this article can be found, in the online version, at http://dx.doi.org/10.1016/j.jseaes.2017.02. 008.

\section{References}

Abbott, M.J., Chamalaun, F.H., 1981. Geochronology of some Banda Arc Volcanics. In: Barber, A.J., Wiryosujono, S. (Eds.), The Geology and Tectonics of Easter
Indonesia. Geological Research and Development Centre, Bandung, pp. 253268.

Aben, F.M., Dekkers, M.J., Bakker, R.R., von Hinsbergen, D.J.J., Zachariasse, W.J., Tate, G.W., McQuarrie, N., Harris, R., Duffy, B., 2014. Unraveling complex magnetic polarity records carried by greigite through an integrated rock magnetic analysis: a case study on Neogene sections in East Timor Geochemistry. Geophys. Geosyst. 15, 2531-2554.

Afonso, J.C., Zlotnik, S., 2011. The subductability of continental lithosphere: the before and after story. In: Brown, D., Ryan, P.D. (Eds.), Arc-Continent Collision. Springer, Berlin Heidelberg, pp. 53-86.

Allègre, C.J., Rousseau, D., 1984. The growth of the continent through geological time studied by Nd isotope analysis of shales. Earth Planet. Sci. Lett. 67, 19-34.

ALS, 2006. Whole rock geochemistry - ME-ICP06 and OA- GRA05. Analysis of major oxides by ICP- AES ALS Minerals,, Winnemucca, Nevada.

ALS, 2009. Geochemical Procedure ME-MS81, Ultra-Trace Level Methods. ALS Global, Winnemuca, Nevada.

Audley-Charles, M.G., 1965. A Miocene gravity slide deposit from Eastern Timor. Geol. Mag. 102, 267-276.

Audley-Charles, M.G., 1967. Greywackes with a primary matrix from the viqueque formation (Upper Miocene-Pliocene), Timor. J. Sediment. Petrol. 37, 5-11.

Audley-Charles, M.G., 1968. The Geology of Portuguese Timor. Geological Society of London, London.

Audley-Charles, M.G., 2011. Tectonic post-collision processes in Timor, In: Hall, R., Cottam, M.A., Wilson, M.E.J. (Eds.), The SE Asian Gateway: History and Tectonics of the Australia-Asia Collision. Geological Society Special Publication 355, London, pp. 241-266.

Audley-Charles, M.G., Carter, D.J., Barber, A.J., Norvick, M.S., Tjokrosapoetro, S., 1979. Reinterpretation of the geology of Seram: implications for the Banda Arcs and northern Australia. J. Geol. Soc. 136, 547-568.

Barber, A.J., 2013. The origin of mélanges: cautionary tales from Indonesia. J. Asian Earth Sci. 76, 428-438.

Barber, A.J., Tjokrosapoetro, S., Charlton, T.R., 1986. Mud volcanoes, shale diapirs, wrench faults and melanges in accretionary complexes, Eastern Indonesia. Am. Assoc. Pet. Geol. Bull. 70, 1729-1741.

Barkham, S.T., 1993. The Structure and Stratigraphy of the Permo-Triassic Carbonate Formations of West Timor, Indonesia. Department of Geology. Royal Holloway and Bedford New College, University of London, London.

Bayona, G., Montes, C., Cardona, A., Jaramillo, C., Ojeda, G., Valencia, V., Ayala-Calvo, C., 2011. Intraplate subsidence and basin filling adjacent to an oceanic arccontinent collision: a case from the southern Caribbean-South America plate margin. Basin Res. 23, 403-422.

Berry, R.F., 1981. Petrology of the Hili Manu Lherzolite, East Timor. J. Geol. Soc. Aust. $28,453-469$.

Berry, R.F., Jenner, G.A., 1982. Basalt geochemistry as a test of the tectonic models of Timor. J. Geol. Soc. London 139, 593-604.

Berry, R.F., McDougall, I., 1986. Interpretation of ${ }^{40} \mathrm{Ar} /{ }^{39} \mathrm{Ar}$ and $\mathrm{K} / \mathrm{Ar}$ dating evidence from the Aileu Formation, East Timor, Indonesia. Chem. Geol. (Isotope Geosci. Sect.) $59,43-58$.

Bhatia, M.R., Crook, K.A.W., 1986. Trace element characteristics of graywackes and tectonic setting discrimination of sedimentary basins. Contrib. Miner. Petrol. 92, 181-193.

Bock, Y., Prawirodirdjo, L., Genrich, J.F., Stevens, C.W., McCaffrey, R., Subarya, C., Puntodewo, S.S.O., Calais, E., 2003. Crustal motion in Indonesia from Global Positioning System measurements. J. Geophys. Res. B: Solid Earth 108.

Boger, S.D., Spelbrink, L.G., Lee, R.I., Sandiford, M., Maas, R., Woodhead, J.D., 2016. Constraints on the origins of the Aileu and Gondwana sequences of Timor from geochemical, Nd isotope, and U-Pb detrital zircon data. J. Asian Earth Sci.

Boynton, W.V., 1983. Cosmochemistry of the rare earth elements: meteorite studies. Rare Earth Elem. Geochem., 63-114

Breen, N.A., Silver, E.A., Hussong, D.M., 1986. Structural styles of an accretionary wedge south of the island of Sumba, Indonesia, revealed by Sea Marc II side scan sonar. Geol. Soc. Am. Bull. 97, 1250-1261.

Brouwer, H.A., 1942. Summary of the geological results of the expeditions. Geological Expeditions to the Lesser Sunda Islands 4, 345-402.

Brown, D., Ryan, P.D., Afonso, J.C., Boutelier, D., Burg, J.P., Byrne, T., Calvert, A., Cook, F., DeBari, S., Dewey, J.F., Gerya, T.V., Harris, R.A., Herrington, R., Konstantinovskaya, E., Reston, T., Zagorevski, A., 2011. Arc-continent collision: the making of an orogen. In: Brown, D., Ryan, P.D. (Eds.), Arc-Continent Collision, Frontiers in Earth Sciences. Springer-Verlag, Berlin, pp. 477-493.

Brown, K., Westbrook, G.K., 1988. Mud diapirism and subcretion in the Barbados Ridge Accretionary Complex: the role of fluids in accretionary processes. Tectonics 7, 613-640.

Cecil, C.B., Dulong, F.T., Harris, R.A., Cobb, J.C., Gluskoter, H.G., Nugroho, H., 2003. Observations on climate and sediment discharge in selected tropical rivers, Indonesia. In: Cecil, C.B., Edgar, T.E. (Eds.), Climate Controls on Stratigraphy. Society for Sedimentary Geology Special Publication, Tulsa, Oklahoma, pp. 2950 .

Chamalaun, F.H., Grady, A.E., von der Borch, C.C., Hartono, H.M.S., 1982. Banda arc tectonics: the significance of the Sumba Island. In: Watkins, J.S., Drake, C.L. (Eds.), Studies in Continental Margin Geology. Amer. Assoc. Petrol. Geologists, pp. 361-375.

Chang, C.P., Angelier, J., Huang, C.Y., Liu, C.S., 2001. Structural evolution and significance of a mélange in a collision belt: the Lichi Mélange and the Taiwan arc-continent collision. Geol. Mag. 138, 633-651.

Chappell, J., Veeh, H.H., 1978. Late Quaternary tectonic movements and sea-level changes at Timor and Atauro Island. Geol. Soc. Am. Bull. 89, 356-368. 
Charlton, T.R., 1989. Stratigraphic correlation across an arc-continent collision zone: Timor and the Australian Northwest Shelf. Aust. J. Earth Sci. 36, 263-274.

Charlton, T.R., 2002a. The petroleum potential of East Timor. APPEA J. 42, 351-369.

Charlton, T.R., 2002b. The structural setting and tectonic significance of the Lolotoi, Laclubar and Aileu metamorphic massifs, East Timor. J. Asian Earth Sci. 20, 851865.

Charlton, T.R., Barber, A.J., Harris, R.A., Barkham, S.T., Bird, P.R., Archbold, N.W., Morris, N.J., Nicoll, R.S., Owen, H.G., Owens, R.M., Sorauf, J.E., Taylor, P.D., Webster, G.D., Whittaker, J.E., 2002. The Permian of Timor: stratigraphy, palaeontology and palaeogeography. J. Asian Earth Sci. 20, 719-774.

Charlton, T.R., Barber, A.J., McGowan, A.J., Nicoll, R.S., Roniewicz, E., Cook, S.E., Barkham, S.T., Bird, P.R., 2009. The Triassic of Timor: lithostratigraphy, chronostratigraphy and palaeogeography. J. Asian Earth Sci. 36, 341-363.

Charlton, T.R., Wall, D., 1994. New biostratigraphic results from the Kolbano area, southern West Timor: implications for the Mesozoic-Tertiary stratigraphy of Timor. J. SE Asian Earth Sci. 9, 113-122.

Cook, P.J., 1974a. Major and trace element geochemistry of sediments from Deep Sea Drilling Project, Leg 27, Sites 259-263, eastern Indian Ocean. Init. Repts. DSDP 27, 481-497.

Cook, P.J., 1974b. Phosphate content of sediments from Deep Sea Sites 259 to 263, Eastern Indian Ocean. Init. Repts. DSDP 27, 455-461.

Cooks, H.E., Zemmels, I., Matti, J.C., 1974. X-ray mineralogy data, eastern Indian Ocean - Leg 27 Deep Sea Drilling Project. Init. Repts. DSDP 27, 535-548.

Cox, N.L., 2009. Variable Uplift From Quaternary Folding Along the Northern Coast of East Timor, based on U-Series Age Determinations of Coral Terraces. Department of Geological Sciences. Brigham Young University, Provo, Utah, p. 151.

Creaser, R., Erdmer, P., Stevens, R., Grant, S., 1997. Tectonic affinity of Nisutlin and Anvil assemblage strata from the Teslin tectonic zone, northern Canadian Cordillera: constraints from neodymium isotope and geochemical evidence. Tectonics 16, 107-121.

de Roever, W.P., 1940. Geological Investigations in the Southwestern Moetis Region (Netherlands Timor). In: Brouwer, H.A. (Ed.), Geological Expedition of the University of Amsterdam to the Lesser Sunda Islands in the South Eastern Part of the Netherlands East Indies 1937. N.V. Noord-Hollandsche Uitgevers Maatschappij, Amsterdam, pp. 97-344.

de Roever, W.P., 1942. Olivine-basalts and their alkaline differentiates in the Permian of Timor. In: Brouwer, H.A. (Ed.), Geological Expedition of the University of Amsterdam to the Lesser Sunda Islands in the South Eastern Part of the Netherlands East Indies 1937. N.V. Noord-Hollandsche Uitgevers Maatschappij, Amsterdam, pp. 211-289.

De Smet, M.E.M., Fortuin, A.R., Troelstra, S.R., Van Marle, L.J., Karmini, M., Tjokrosapoetro, S., Hadiwasastra, S., 1990. Detection of collision-related vertical movements in the Outer Banda Arc (Timor, Indonesia), using micropaleontological data. J. SE Asian Earth Sci. 4, 337-356.

Dean, W.E., 1974. Determination of carbonate and organic matter in calcareous sediments and sedimentary rocks by loss on ignition: comparison with other methods. J. Sediment. Petrol. 44, 242-248.

DeCelles, P.G., Gehrels, G.E., Quade, J., Ojha, T.P., Kapp, P.A., Upreti, B.N., 1998. Neogene foreland basin deposits, erosional unroofing, and the kinematic history of the Himalayan fold-thrust belt, western Nepal. Geol. Soc. Am. Bull. 110, 2-21.

Dewey, J., Mange, M., 2000. Petrography of Ordovician and Silurian sediments in the western Irish Caledonides: tracers of a short-lived Ordovician continent-arc collision orogeny and the evolution of the Laurentian Appalachian-Caledonian margin, pp. 55-107.

Dorsey, R.J., 1988. Provenance evolution and unroofing history of a modern arccontinent collision; evidence from petrography of Plio-Pleistocene sandstones, eastern Taiwan. J. Sediment. Res. 58, 208-218.

Duerto, L., McClay, K., 2011. Role of the shale tectonics on the evolution of the Eastern Venezuelan Cenozoic thrust and fold belt. Mar. Pet. Geol. 28, $81-108$.

Duffy, B., 2013. The Structural and Geomorphic Development of Active Collisional Orogens, from Single Earthquake to Million Year Timescales, Timor Leste and New Zealand. Department of Geological Sciences, University of Canterbury, Christchurch, p. 238.

Duffy, B., Quigley, M.C., Harris, R., Ring, U., 2013. Arc-parallel extrusion of the Timor sector of the Banda arc-continent collision. Tectonics 32, 641-660.

Earle, M.M., 1980. A Study of Boi and Mollo, Two Metamorphic Massifs on Timor, Eastern Indonesia. University of London, London, p. 240.

Earle, M.M., 1981. The metamorphic rocks of Boi, Timor, eastern Indonesia. In: Barber, A.J., Wiryosujono, S. (Eds.), The Geology and Tectonics of Eastern Indonesia. GRDC Spec. Pub, pp. 239-251.

Earle, M.M., 1983. Continental margin origin for cretaceous radiolarian chert in western Timor. Nature 305, 129-130.

Effendi, A.C., Apandi, T., 1981. Laporan Geologi Lembar Sumba-Nusa Tenggara Timur (Geological Map of Sumba, East Nusa Tenggara), 1:250,000. Geological Research and Development Centre, Indonesia, Bandung.

Ehrenberg, S.N., Nadeau, P.H., 2002. Postdepositional Sm/Nd fractionation in sandstones: implications for neodymium-isotope stratigraphy. J. Sediment. Res. 72, 304-315.

Elburg, M.A., Foden, J.D., van Bergen, M.J., Zulkarnain, I., 2005. Australia and Indonesia in collision: geochemical sources of magmatism. J. Volcanol. Geoth. Res. 140, 25-47.

Ely, K.S., Sandiford, M., Hawke, M.L., Phillips, D., Quigley, M.C., Reis, J.E.d., 2011. Evolution of Ataúro Island: temporal constraints on subduction processes beneath the Wetar zone, Banda Arc. J. Asian Earth Sci. 41, 477-493.
Ely, K.S., Sandiford, M., Phillips, D., Boger, S.D., 2014. Detrital zircon U-Pb and ${ }^{40} \mathrm{Ar} /{ }^{39} \mathrm{Ar}$ hornblende ages from the Aileu Complex, Timor-Leste: provenance and metamorphic cooling history. J. Geol. Soc. 171, 299-309.

Falloon, T., Berry, R.F., Robinson, P., Stolz, A.J., 2006. Whole-rock geochemistry of the Hili Manu peridotite, East Timor: implications for the origin of Timor ophiolites. Aust. J. Earth Sci. 53, 637-649.

Fedo, C.M., Nesbitt, H.W., Young, G.M., 1995. Unravelling the effects of potassium metasomatism in sedimentary rocks and paleosols, with implications for paleoweathering conditions and provenance. Geology 23, 921-924.

Festa, A., Pini, G.A., Dilek, Y., Codegone, G., 2010. Mélanges and mélange-forming processes: a historical overview and new concepts. Int. Geol. Rev. 52, $1040-$ 1105.

Floyd, P.A., Leveridge, B.E., Franke, W., Shail, R., Dörr, W., 1990. Provenance and depositional environment of Rhenohercynian synorogenic greywackes from the Giessen Nappe, Germany. Geol. Rundsch. 79, 611-626.

Fortuin, A.R., van der Werff, W., Wensink, H., 1997. Neogene basin history and paleomagnetism of a rifted and inverted forearc region, on- and offshore Sumba, Eastern Indonesia. J. Asian Earth Sci. 15, 61-88.

Gapais, D., 1989. Shear structures within deformed granites: mechanical and thermal indicators. Geology 17, 1144-1147.

Genrich, J.F., Bock, Y., McCaffrey, R., Calais, E., Stevens, C.W., Subarya, C., 1996. Accretion of the southern banda arc to the Australian plate margin determined by global positioning system measurements. Tectonics 15, 288-295.

Gingele, F.X., De Deckker, P., Hillenbrand, C.-D., 2001. Clay mineral distribution in surface sediments between Indonesia and NW Australia - source and transport by ocean currents. Mar. Geol. 179, 135-146.

Gourlan, A.T., Meynadier, L., Allegre, C.J., 2008. Tectonically driven changes in the Indian Ocean circulation over the last $25 \mathrm{Ma}$ : neodymium isotope evidence. Earth Planet. Sci. Lett. 267, 353-364.

Guo, O., Xiao, W. Windley, B.F., Mao, O, Han, C., Ou, J., Ao, S., Li, J., Song . D., Yong, Y., 2012. Provenance and tectonic settings of Permian turbidites from the Beishan Mountains, NW China: implications for the Late Paleozoic accretionary tectonics of the southern Altaids. J. Asian Earth Sci. 49, 54-68.

Gustafson, J.K., 1946. Two occurrences of chloritoid as a hydrothermal mineral in igneous rocks. Am. Mineral. 31, 313-316.

Haig, D.W., 2012. Palaeobathymetric gradients across Timor during 5.7-3.3 Ma (latest Miocene-Pliocene) and implications for collision uplift. Palaeogeogr. Palaeoclimatol. Palaeoecol. 331-332, 50-59.

Haig, D.W., Bandini, A.N., 2013. Middle Jurassic Radiolaria from a siliceous argillite block in a structural melange zone near Viqueque, Timor Leste: paleogeographic implications. J. Asian Earth Sci. 75, 71-81.

Haig, D.W., McCartain, E., 2007. Carbonate pelagites in the post-Gondwana succession (Cretaceous - Neogene) of East Timor. Aust. J. Earth Sci. 54, 875-897.

Haig, D.W., McCartain, E., Barber, L., Backhouse, J., 2007. Triassic-lower Jurassic foraminiferal indices for bahaman-type carbonate-bank limestones, Cablac Mountain, East Timor. J. Foramin. Res. 37, 248-264.

Haig, D.W., McCartain, E., Keep, M., Barber, L., 2008. Re-evaluation of the Cablac Limestone at its type area, East Timor: revision of the Miocene stratigraphy of Timor. J. Asian Earth Sci. 33, 366-378.

Halferdahl, L.B., 1961. Chloritoid: its composition, X-ray and optical properties, stability, and occurrence. J. Petrol. 2, 49-135.

Hall, R., Wilson, M.E.J., 2000. Neogene sutures in eastern Indonesia. J. Asian Earth Sci. $18,781-808$.

Harris, R.A., 1991. Temporal distribution of strain in the active Banda orogen: a reconciliation of rival hypotheses. J. SE Asian Earth Sci. 6, 373-386.

Harris, R.A., 1992. Peri-collisional extension and the formation of Oman-type ophiolites in the Banda arc and Brooks Range, In: Parson, L.M., Murton, B.J. Browning, P. (Eds.), Ophiolites and their modern oceanic analogues. Geological Society of London Special Publication 60, Bath, England, pp. 301-325.

Harris, R.A., 2006. Rise and fall of the Eastern Great Indonesian arc recorded by the assembly, dispersion and accretion of the Banda Terrane, Timor. Gondwana Res. 10, 207-231.

Harris, R.A., 2011. The nature of the Banda Arc-continent collision in the Timor Region. In: Brown, D., Ryan, P.D. (Eds.), Arc-Continent Collision. Springer, Heidelberg, Berlin, pp. 163-211.

Harris, R.A., Cecil, C.B., Dulong, F.T., Nugroho, H., Anonymous, 2008. Is sediment discharge controlled more by climate or tectonics? Studies of suspended and dissolved loads from rivers in active orogens of Indonesia. J. Himalayan Geol. 29, 32-33.

Harris, R.A., Long, T., 2000. The Timor ophiolite, Indonesia: Model or myth?, In: Dilek, Y., Moores, E., Elthon, D., Nicolas, A. (Eds.), Ophiolites and Oceanic Crust: New Insights from Field Studies and the Ocean Drilling Program. Geological Society of America Special Paper 349, pp. 321-330.

Harris, R.A., Sawyer, R.K., Audley-Charles, M.G., 1998. Collisional melange development: geologic associations of active melange-forming processes with exhumed melange facies in the western Banda orogen, Indonesia. Tectonics 17, $458-479$.

Harris, R.A., Vorkink, M.W., Prasetyadi, C., Zobell, E., Roosmawati, N., Apthorpe, M., 2009. Transition from subduction to arc-continent collision: geologic and neotectonic evolution of Savu Island, Indonesia. Geosphere 5, 152-171.

Heirtzler, J.R., Veevers, J.J., Bolli, H.M., Carter, A.N., Cook, P.J., Krasheninnikov, V., McKnight, B.K., Proto-Decima, F., Renz, G.W., Robinson, P.T., Rocker Jr., K., Thayer, P.A., 1974. Site 262. Initial Reports on the Deep Sea Drilling Project 27, $193-278$.

Helmers, H., Sopaheluwakan, J., Tjokrosapoetro, S., Nila, E.S., 1989. High-grade metamorphism related to peridotite emplacement near Atapupu, Timor with 
reference to the Kaibobo peridotite on Seram, Indonesia. Neth. J. Sea Res. 24, 357-371.

Herrington, R.J., Scotney, P.M., Roberts, S., Boyce, A.J., Harrison, D., 2011. Temporal association of arc-continent collision, progressive magma contamination in arc volcanism and formation of gold-rich massive sulphide deposits on Wetar Island (Banda arc). Gondwana Res. 19, 583-593.

Hinschberger, F., Malod, J.-A., Dyment, J., Honthaas, C., Rehault, J.-P., Burhanuddin, S., 2001. Magnetic lineations constraints for the back-arc opening of the late Neogene South Banda Basin (eastern Indonesia). Tectonophysics 333, 47-59.

Hinschberger, F., Malod, J.A., Réhault, J.P., Villeneuve, M., Royer, J.Y., Burhanuddin, S., 2005. Late Cenozoic geodynamic evolution of eastern Indonesia. Tectonophysics 404, 91-118.

Hiscott, R.N., 1984. Ophiolitic source rocks for Taconic-age flysch: trace-element evidence. Geol. Soc. Am. Bull. 95, 1261-1267.

Honthaas, C., Réhault, J.P., Maury, R.C., Bellon, H., Hémond, C., Malod, J.A., Cornée, J. J. Villeneuve, M., Cotten, J., Burhanuddin, S., Guillou, H., Arnaud, N., 1998. A Neogene back-arc origin for the Banda Sea basins: geochemical and geochronological constraints from the Banda ridges (East Indonesia). Tectonophysics 298, 297-317.

Hopper, R.W., 1942. Nederlandsche Pacific Petroleum Maatschappij preliminary reconnaissance report Netherlands Pacific Petroleum Company (unpublished report).

Ishikawa, A., Kaneko, Y., Kadarusman, A., Ota, T., 2007. Multiple generations of forearc mafic-ultramafic rocks in the Timor-Tanimbar ophiolite, eastern Indonesia. Gondwana Res. 11, 200-217.

Johnston, C.R., Bowin, C.O., 1981. Crustal reactions resulting from the mid-Pliocene to Recent continent-island arc collision in the Timor Region. BMR J. Austral. Geol. Geophys. 6, 223-243.

Jones, C.E., Halliday, A.N., Rea, D.K., Owen, R.M., 1994. Neodymium isotopic variations in North Pacific modern silicate sediment and the insignificance of detrital REE contributions to seawater. Earth Planet. Sci. Lett. 127, 55-66.

Keep, M., Haig, D.W., 2010. Deformation and exhumation in Timor: distinct stages of a young orogeny. Tectonophysics $483,93-111$.

Kenyon, C.S., 1974. Stratigraphy and Sedimentology of the Late Miocene to Quaternary Deposits in Timor. University of London.

Koulali, A., Susilo, S., McClusky, S., Meilano, I., Cummins, P., Tregoning, P., Lister, G. Efendi, J., Syafi'i, M.A., 2016. Crustal strain partitioning and the associated earthquake hazard in the eastern Sunda-Banda Arc. Geophys. Res. Lett. 43 1943-1949.

Kreemer, C., Holt, W.E. Goes, S., Govers, R., 2000. Active deformation in eastern Indonesia and the Philippines from GPS and seismicity data. J. Geophys. Res. B: Solid Earth 105, 663-680.

Linthout, K., Helmers, H., Sopaheluwakan, J., 1997. Late Miocene obduction an microplate migration around the southern Banda Sea and the closure of the Indonesian Seaway. Tectonophysics 281, 17-30.

Liu, Y.G., Miah, M.R.U., Schmitt, R.A., 1988. Cerium: a chemical tracer for paleooceanic redox conditions. Geochim. Cosmochim. Acta 52, 1361-1371.

Lourens, L.J., Hilgen, F.J., Shackleton, N.J., Laskar, J., Wilson, D., 2004. The Neogene period. In: Gradstein, F.M., Ogg, J.G., Smith, A.G. (Eds.), Geological Time Scale 2004. Cambridge University Press, 409, p. 440.

Martin, E.E., Scher, H., 2006. A Nd isotopic study of southern sourced waters and Indonesian throughflow at intermediate depths in the Cenozoic Indian Ocean. Geochem. Geophys. Geosyst. 7.

McCulloch, M.T., Wasserburg, G.J., 1978. Sm-Nd and Rb-Sr chronology of continental crust formation. Science 200, 1003-1011.

McLennan, S.M., 1989. Rare earth elements in sedimentary rocks: influence of provenance and sedimentary processes. In: Lipin, B.R., McKay, G.A. (Eds.), Geochemistry and Mineralogy of Rare Earth Elements, pp. 169-200.

McLennan, S.M., Hemming, S., McDaniel, D.K., Hanson, G.N., 1993. Geochemical approaches to sedimentation, provenance, and tectonics, In: Johnsson, M.J. Basu, A. (Eds.), Processes Controlling the Composition of Clastic Sediments, Geological Society of America Special Paper 284, Boulder, Colorado, pp. 21-40.

Merritts, D., Eby, R., Harris, R.A., Edwards, R.L., Chang, H., 1998. Variable rates of Late Quaternary surface uplift along the Banda Arc- Australian plate collision zone, eastern Indonesia, In: Stewart, I., Vita-Finzi, C. (Eds.), Coastal tectonics. Geological Society Special Publication, pp. 213-224.

Metcalfe, I., 1996. Pre-Cretaceous evolution of SE Asian terranes, In: Hall, R. Blundell, D.J. (Eds.), Tectonic Evolution of Southeast Asia. Geological Society of London Special Publication 106, Bath, England, pp. 97-122.

Miller, R.G., O'Nions, R.K., 1984. The provenance and crustal residence ages of British sediments in relation to palaeogeographic reconstructions. Earth Planet. Sci. Lett. 68, 459-470.

Mook, D.H., Hoskin, C.M., 1982. Organic determinations by ignition: caution advised. Estuar. Coast. Shelf Sci. 15, 697-699.

Morris, J.D., Gill, J.B., Schwartz, D., Silver, E.A., 1984. Late Miocene to recent Band Sea volcanism, III: isotopic compositions. Eos Trans. AGU 65, 1135.

Murray, R.W., Buchholtz Ten Brink, M.R., Gerlach, D.C., Russ Iii, G.P., Jones, D.L. 1991. Rare earth, major, and trace elements in chert from the Franciscan Complex and Monterey Group, California: assessing REE sources to fine-grained marine sediments. Geochim. Cosmochim. Acta 55, 1875-1895.

Nagel, S., Castelltort, S., Garzanti, E., Lin, A.T., Willett, S.D., Mouthereau, F., Limonta, M., Adatte, T. 2014. Provenance evolution during arc-continent collision: sedimentary petrography of Miocene to Pleistocene sediments in the western Foreland Basin of Taiwan. J. Sediment. Res. 84, 513-528.

Nesbitt, H.W., Young, G.M., 1982. Early proterozoic climates and plate motions inferred from major element chemistry of lutites. Nature 299, 715-717.
Nesbitt, H.W., Young, G.M., 1989. Formation and diagenesis of weathering profiles. J. Geol. 97, 129-147.

Nesbitt, H.W., Young, G.M., McLennan, S.M., Keays, R.R., 1996. Effects of chemical weathering and sorting on the petrogenesis of siliciclastic sediments, with implications for provenance studies. J. Geol. 104, 525-542.

Nexer, M., Authemayou, C., Schildgen, T., Hantoro, W.S., Molliex, S., Delcaillau, B., Pedoja, K., Husson, L., Regard, V., 2015. Evaluation of morphometric proxies for uplift on sequences of coral reef terraces: a case study from Sumba Island (Indonesia). Geomorphology 241, 145-159.

Nguyen, N., Duffy, B., Shulmeister, J., Quigley, M.C., 2013. Rapid Pliocene uplift of Timor. Geology 41, 179-182.

Nugroho, H., Harris, R.A., Lestariya, A.W., Maruf, B., 2009. Plate boundary reorganization in the active Banda arc-continent collision: insights from new GPS measurements. Tectonophysics 479, 52-65.

Park, S.-I., Kwon, S., Kim, S.W., 2014. Evidence for the Jurassic arc volcanism of the Lolotoi complex, Timor: tectonic implications. J. Asian Earth Sci.

Pirazzoli, P.A., Radtke, U., Hantoro, W.S., Jouannic, C., Hoang, C.T., Causse, C., Best, M. B., 1993. A one million-year-long sequence of marine terraces on Sumba Island, Indonesia. Mar. Geol. 109, 221-236.

Pourmand, A., Dauphas, N., Ireland, T.J., 2012. A novel extraction chromatography and MC-ICP-MS technique for rapid analysis of REE, Sc and Y: revising CIchondrite and Post-Archean Australian Shale (PAAS) abundances. Chem. Geol. 291, 38-54.

Pownall, J.M., 2015. UHT metamorphism on Seram, eastern Indonesia: reaction microstructures and P-T evolution of spinel-bearing garnet-sillimanite granulites from the Kobipoto Complex. J. Metamorph. Geol. 33, 909-935.

Pownall, J.M., Hall, R., Armstrong, R.A., Forster, M.A., 2014. Earth's youngest known ultrahigh-temperature granulites discovered on Seram, eastern Indonesia. Geology 42, 279-282.

Pownall, J.M., Hall, R., Watkinson, I.M., 2013. Extreme extension across Seram and Ambon, eastern Indonesia: evidence for Banda slab rollback. Solid Earth 4, 277 314.

Price, N.J., Audley-Charles, M.G., 1987. Tectonic collision processes after plate rupture. Tectonophysics $140,121-129$.

Prider, R.T., 1947. Chloritoid at Kalgoorlie. Am. Mineral. 32, 471-474.

Quigley, M.C., Duffy, B., Woodhead, J., Hellstrom, J., Moody, L., Horton, T., Suares, J., Fernandes, L., 2012. U/Pb dating of a terminal Pliocene coral from the Indonesian Seaway. Mar. Geol. 311-314, 57-62.

Quigley, M.C., Sandiford, M., Cupper, M.L., 2007. Distinguishing tectonic from climatic controls on range-front sedimentation. Basin Res. 19, 491-505.

Rangin, C., Bellon, H., Benard, F., Letouzey, J., Muller, C., Sanudin, T., 1990. Neogene arc-continent collision in Sabah, Northern Borneo (Malaysia). Tectonophysics 183, 305-319.

Rigg, J.W.D., Hall, R., 2012. Neogene development of the Savu Forearc Basin, Indonesia. Mar. Pet. Geol. 32, 76-94.

Roosmawati, N., Harris, R.A., 2009. Surface uplift history of the incipient Banda arccontinent collision: geology and synorogenic foraminifera of Rote and Savu Islands, Indonesia. Tectonophysics 479, 95-110.

Roser, B.P., Korsch, R.J., 1988. Provenance signatures of sandstone-mudstone suites determined using discriminant function analysis of major-element data. Chem. Geol. 67, 119-139.

Rosidi, H.M.D., Suwitodirdjo, K., Tjokosaproetro, S., 1981. Geologic Map of the Kupang-Atambua Quadrangles, Timor. Geological Research and Development Centre, Bandung, Indonesia.

Rutherford, E., Burke, K., Lytwyn, J., 2001. Tectonic history of Sumba Island, Indonesia, since the Late Cretaceous and its rapid escape into the forearc in the Miocene. J. Asian Earth Sci. 19, 453-479.

Ryan, P.D., 2008. Preservation of forearc basins during island arc-continent collision: some insights from the Ordovician of western Ireland, In: Draut, A. E., Clift, P.D., Scholl, D.W. (Eds.), Formation and Applications of the Sedimentary Record in Arc Collision Zones. Geological Society of America Special Paper, pp. $1-9$.

Sani, K., Jacobson, M.L., Sigit, R., 1995. The thin-skinned thrust structures of Timor. Proceedings of the Indonesian Petroleum Association 24th Annual Convention, 277-293.

Santisteban, J.I., Mediavilla, R., Lopez-Pamo, E., Dabrio, C.J., Blanca Ruiz Zapata, M., Jose Gil Garcia, M. Castano, S., Martınez-Alfaro, P.E., 2004 Loss on ignition: qualitative or quantitative method for organic matter and carbonate mineral content in sediments? J. Paleolimnol. 32, 287-299.

Sawyer, R.K., Sani, K., Brown, S., 1993. The stratigraphy and sedimentology of West Timor, Indonesia. Proceedings of the Indonesian Petroleum Association, Twenty Second Annual Convention, 533-574.

Schubert, J.K., Kidder, D.L., Erwin, D.H., 1997. Silica-replaced fossils through the Phanerozoic. Geology 25, 1031-1034.

Shields, G., Stille, P., 2001. Diagenetic constraints on the use of cerium anomalies as palaeoseawater redox proxies: an isotopic and REE study of Cambrian phosphorites. Chem. Geol. 175, 29-48.

Simons, A.L, 1940. Geological investigations in north-east Netherlands Timor. In: Brouwer, H.A. (Ed.), Geological Expedition to the Lesser Sunda Islands under the Leadership of H. A. Brouwer. Noord-Hollandsche Uitgevers Maatschappij, Amsterdam, pp. 107-213.

Smith, W.H.F., Sandwell, D.T., 1997. Global seafloor topography from satellite altimetry and ship depth soundings. Science 277, 1957-1962.

Snyder, D.B., Milsom, J., Prasetyo, H., 1996. Geophysical evidence for local indentor tectonics in the Banda Arc east of Timor, In: Hall, R., Blundell, D.J. (Eds.), 
Tectonic evolution of Southeast Asia. Geological Society of London Special Publication 106, Bath, England, pp. 61-73.

Sopaheluwakan, J., Helmers, H., Tjokrosapoetro, S., Surya Nila, E., 1989. Medium pressure metamorphism with inverted thermal gradient associated with ophiolite nappe emplacement in Timor. Neth. J. Sea Res. 24, 333-343.

Spakman, W., Hall, R., 2010. Surface deformation and slab-mantle interaction during Banda arc subduction rollback. Nat. Geosci. 3, 562-566.

Standley, C.E., Harris, R.A., 2009. Tectonic evolution of forearc Nappes of the active Banda arc-continent collision: origin, age, metamorphic history and structure of the Lolotoi Complex, East Timor. Tectonophysics. http://dx.doi.org/10.1016/ j.tecto.2009.01.034.

Sun, S.S., McDonough, W.F., 1989. Chemical and isotopic systematics of oceanic basalts: implications for mantle composition and processes. In: Saunders, A.D., Norry, M.J. (Eds.), Magmatism in the Ocean Basins; Geological Society Special Publication. Blackwell Scientific Publications, Oxford, UK, pp. 313-345.

Tate, G.W., 2014. Structural Deformation, Exhumation, and Uplift of the Timor FoldThrust Belt. Department of Geosciences. Princeton University, p. 273.

Tate, G.W., McQuarrie, N., von Hinsbergen, D.J.J., Bakker, R.R., Harris, R., Willet, S., Reiners, P., Fellin, M.G., Ganerød, M., Zachariasse, J.W., 2014. Resolving spatial heterogeneities in exhumation and surface uplift in East Timor: constraints of deformation processes in young orogens. Tectonics.

Tate, G.W., McQuarrie, N., van Hinsbergen, D.J.J., Bakker, R.R., Harris, R., Jiang, H., 2015. Australia going down under: quantifying continental subduction during arc-continent accretion in Timor-Leste. Geosphere.

Taylor, S.R., McLennan, S.M., 1985. The Continental Crust: Its Composition and Evolution. An Examination of the Geochemical Record Preserved in Sedimentary Rocks. Blackwell Scientific, Oxford.

Torabi, G., Arai, S., Koepke, J., 2011. Metamorphosed mantle peridotites from central Iran (Jandaq area, Isfahan province). Neues Jahrb. Geol. Palaontol. - A 261, 129150.

Tullis, J., 1983. Deformation of feldspars. Rev. Am. Mineral. Soc. 2, 297-323.

Unterschutz, J., Creaser, R., Erdmer, P., Thompson, R., Daughtry, K., 2002. North American margin origin of Quesnel terrane strata in the southern Canadian Cordillera: inferences from geochemical and $\mathrm{Nd}$ isotopic characteristics of Triassic metasedimentary rocks. Geol. Soc. Am. Bull. 114, 462-475.

Van Andel, T.H., Veevers, J.J., 1967. Morphology and sediments of the Timor Sea. Bureau of Mineral Resources, Canberra.

van Marle, L.J., 1991. Late Cenozoic palaeobathymetry and geohistory analysis of Central West Timor, eastern Indonesia. Mar. Pet. Geol. 8, 22-34.

van West, F.P., 1941. Geological Investigations in the Miomaffo Region (Netherlands Timor). Noord-Hollandsche Uitg. Mij, Amsterdam.

Vance, D., Scrivner, A.E., Beney, P., Staubwasser, M., Henderson, G.M., Slowey, N.C., 2004. The use of foraminifera as a record of the past neodymium isotope composition of seawater. Paleoceanography 19, PA2009.

Veevers, J.J., Falvey, D.A., Robins, S., 1978. Timor trough and Australia: facies show topographic wave migrated $80 \mathrm{~km}$ during the past $3 \mathrm{~m}$.y. Tectonophysics 45 , 217-227.
Venkatesh, V., Malhotra, P.D., 1960. Chloritoid from Mosaboni, Bihar. Rec. Geol. Surv. India 86, 545-550.

Vita-Finzi, C., Hidayat, S., 1991. Holocene uplift in West Timor. J. SE Asian Earth Sci. 6, 387-393.

Voll, G. 1976. Recrystallization of quartz, biotite and feldspars from Erstfeld to the Leventina Nappe, Swiss Alps, and its geological significance. Schweiz. Mineral. Petrogr. Mitt. 56, 641-647.

Vroon, P.Z., Bergen, M.J.V., Klaver, G.J., White, W.M., 1995. Strontium, neodymium, and lead isotopic and trace-element signatures of the East Indonesian sediments: provenance and implications for Banda Arc magma genesis. Geochim. Cosmochim. Acta 59, 2573-2598.

Vroon, P.Z., Van Bergen, M.J., Forde, E.J., 1996. Pb and Nd isotope constraints on the provenance of tectonically dispersed continental fragments in east Indonesia, In: Hall, R., Blundell, D.J. (Eds.), Tectonic evolution of Southeast Asia. The Geological Society Special Publication No. 106, Bath, England.

Vroon, P.Z., Van Bergen, M.J., White, W.M., Varekamp, J.C., 1993. Sr-Nd-Pb isotope systematics of the Banda Arc, Indonesia: combined subduction and assimilation of continental material. J. Geophys. Res. 98, 22349-22366.

Wade, B.S., Pearson, P.N., Berggren, W.A., Paelike, H., 2011. Review and revision of Cenozoic tropical planktonic foraminiferal biostratigraphy and calibration to the geomagnetic polarity and astronomical time scale. Earth-Sci. Rev. 104, 111 142.

Watkinson, I.M., Hall, R., Ferdian, F., 2011. Tectonic re-interpretation of the BanggaiSula-Molucca Sea margin, Indonesia, In: Hall, R., Cottam, M.A., Wilson, M.E.J. (Eds.), The SE Asian Gateway: History and Tectonics of the Australia-Asia Collision. Geological Society Special Publication 355, London, pp. 203-224.

Wensink, H., 1994. Paleomagnetism of rocks from Sumba: tectonic implications since the late Cretaceous. J. SE Asian Earth Sci. 9, 51-65.

Wensink, H., van Bergen, M.J., 1995. The tectonic emplacement of Sumba in the Sunda-Banda Arc: paleomagnetic and geochemical evidence from the early Miocene Jawila volcanics. Tectonophysics 250, 15-30.

Willett, S.D., Slingerland, R., Hovius, N., 2001. Uplift, shortening, and steady state topography in active mountain belts. Am. J. Sci. 301, 455-485.

Williams, P.R., Pigram, C.J., Dow, D.B., Amiruddin, 1984. Melange production and the importance of shale diapirism in accretionary terrains. Nature 309, 145-146.

Winchester, J.A., Floyd, P.A., 1977. Geochemical discrimination of different magma series and their differentiation products using immobile elements. Chem. Geol. 20, 325-343.

Yu, H.-S., Jiunn Chenn, L., 1995. Development of the shale diapir-controlled Fangliao Canyon on the continental slope off southwestern Taiwan. J. SE Asian Earth Sci. $11,265-276$.

Zhu, B., Kidd, W.S.F., Rowley, D.B., Currie, B.S., Shafique, N., 2005. Age of initiation of the India-Asia collision in the East-Central Himalaya. J. Geol. 113, 265-285. 